\title{
Диагностика и лечение новой коронавирусной инфекции в многопрофильном стационаре:
}

\section{опЫт ГКБ №№15}

Байкова Оксана Алексеевна, доктор медицинских наук, профессор, заведующий терапевтическим отделением ГБУЗ ГКБ №15 им. О.М. Филатова (Москва), E-mail: baikova-o.alekseevna@bk.ru

Вечорко Валерий Иванович, кандидат медицинских наук, главный врач ГБУЗ ГКБ №15 им. О.М. Филатова (Москва),

Дорошенко Дмитрий Александрович, кандидат медицинских наук, заведующий отделением лучевых и функциональных методов исследования ГБУЗ ГКБ №15 им. О.М. Филатова (Москва),

Медников Григорий Николаевич, заведующий патологоанатомическим отделением ГБУЗ ГКБ №15 им. О.М. Филатова (Москва),

Гришин Дмитрий Валерьевич, врач-невролог ГБУЗ ГКБ №15 им. О.М. Филатова (Москва), E-mail: tulip270@mail.ru

Государственное бюджетное учреждение здравоохранения города Москвы «Городская клиническая больница № 15 им. О.М. Филатова Департамента здравоохранения города Москвы»

\section{Краткая аннотация}

Статья посвящена проблемам этиологии, патогенеза, диагностики, клиники и лечения COVID-19, вызываемого коронавирусом SARS-CoV-2 на основе обзора литературных источников, а также собственного опыта курации пациентов с COVID-19 клиницистами инфекционного госпиталя на базе перепрофилированной ГКБ 15 им. О.М. Филатова. Представляло интерес изменение взглядов медицинского сообщества на патогенез и подходы к лечению данного заболевания за период пандемии.

\section{Ключевые слова}

Пандемия. Коронавирус SARS-CoV-2. Инфекционное заболевание COVID19. Цитокиновый шторм. Дыхательная недостаточность. ОРДС. Диагностика COVID-19. Патогенетическая терапия. 


\section{Введение}

COVID-19 (аббревиатура от англ. COronaVIrus Disease 2019) - острая

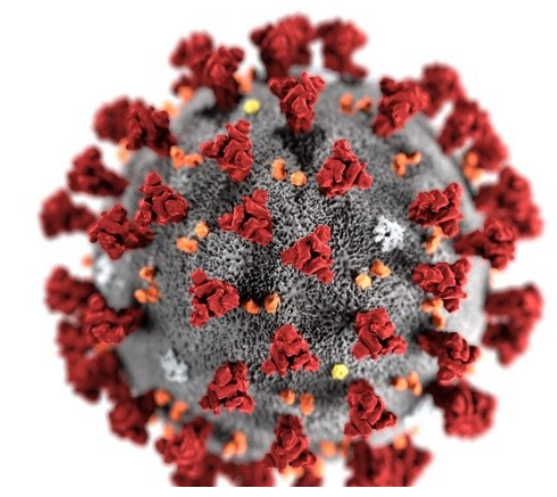

Рисунок 1 Схема вируса COVID-19 респираторная инфекция, вызываемая

коронавирусом SARS-CoV$\underline{2}$ (2019-nCoV), для которой характерна вариабельность течения. Может протекать как в форме ОРВИ лёгкого течения [39,4], так и в тяжёлой форме [17].

$\begin{array}{cr}\text { Наиболее } & \text { частым } \\ \text { осложнением } & \text { является }\end{array}$

вирусная пневмония, способная приводить к ОРДС и последующей острой дыхательной недостаточностью (ОДН), при которых чаще всего необходима кислородная терапия и респираторная поддержка [23]. К клиническим симптомам относятся чаще всего лихорадка, утомляемость и сухой кашель [6]. Впрочем, отмечена высокая вариабельность клинической картины. Довольно высокая контагиозность привела к стремительному распространению заболевания по всему миру. Передаётся вирус воздушнокапельным путём, либо через поверхности с последующим занесением в глаза, нос или рот [36].

Заболевание вызывается новым вирусом, против которого у людей изначально нет приобретённого иммунитета [36], к инфекции восприимчивы люди всех возрастных категорий.

Несмотря на уже многомесячный период пандемии до сих пор нет специфического противовирусного средства лечения и профилактики [39].

В большинстве случаев (около 80\%) какое-либо специфическое лечение не требуется, а выздоровление происходит само по себе [39,6]. В тяжёлых случаях применяются средства для поддержания функции жизненно важных органов. Примерно 15\% - это тяжёлые случаи, еще в 5\% состояние больных расценивается как критическое [13].

11 марта 2020 г. распространение вируса было признано пандемией [29]. Ситуация быстро развивалась, увеличивалось количество заболевших и погибших. Ведутся различные научные и клинические исследования. Актуальным является свободный доступ и обмен информацией, связанной с новым заболеванием. 
Но это первая в истории человечества пандемия, которая может быть взята под контроль [37]. Пандемия опасна тем, что одновременное заболевание инфекцией множества людей может привести к перегруженности системы здравоохранения, которая может оказаться не готова к необычайно большому количеству тяжелобольных пациентов [16]. Поэтому наиболее важной ответной мерой по отношению к инфекции могут являться не столько лечебные мероприятия, сколько снижение скорости её распространения [13]. Эпидемия закончится как только у населения выработается коллективный иммунитет [34].

\section{Этиология}

Итак, этиологическим агентом COVID-19 является ранее неизвестный бета-коронавирус SARS-CoV-2, который был обнаружен в образцах жидкости, взятой из лёгких группы пациентов с пневмонией в китайском городе Ухань, в декабре 2019 г. Вирус относится к подроду Sarbecovirus и является седьмым по счёту известным коронавирусом, способным заражать человека [25].

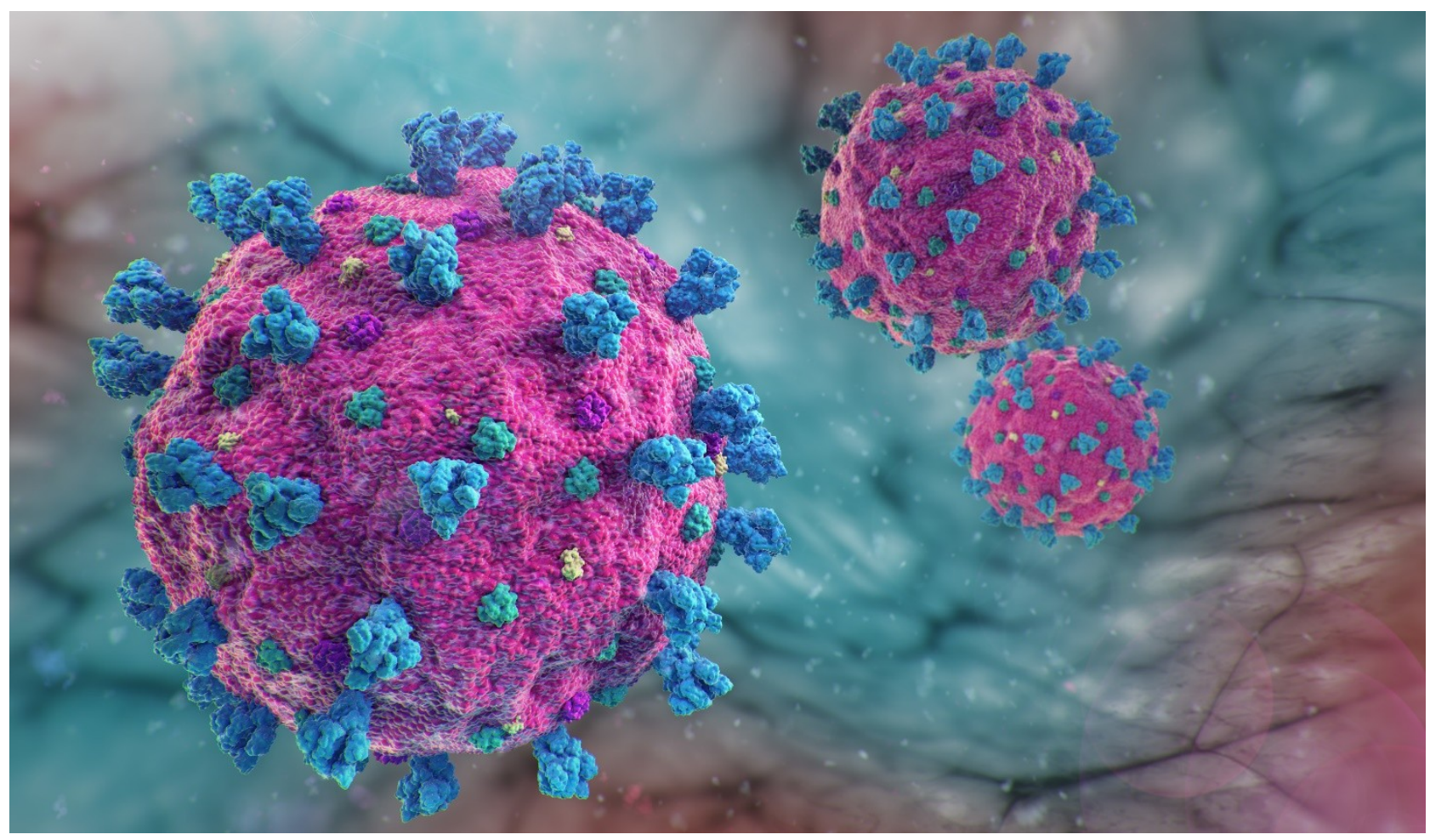

Рисунок 2 Схема вируса

SARS-CoV-2 является РHK-содержащим вирусом с оболочкой, является результатом рекомбинации коронавируса летучих мышей с другим, пока ещё неизвестным, коронавирусом. Предполагается, что человеку вирус передался от панголина [25,18]. Полный геном вируса уже расшифрован [25].

Вирус попадает в клетку присоединением белка-пепломера к рецептору ангиотензинпревращающему ферменту 2 типа в клетке [39]. Входу в клетку 
также способствует предварительная преактивация пепломера фурином, которая отсутствовала у вируса SARS [22]. После присоединения к рецептору вирус SARS-CoV-2 использует рецепторы клетки и эндосомы для проникновения [28]. Помогает проникновению протеаза TMPRSS2 [14]. После заражения вирус распространяется через слизь по дыхательным путям, вызывая большой выброс цитокинов и иммунный ответ в организме. При этом наблюдается снижение количества лимфоцитов в крови, в частности Тлимфоцитов. На борьбу с вирусом расходуется слишком большое количество лимфоцитов. Это снижает защитные способности иммунной системы и может приводить к обострению различных хронических заболеваний [22].

Высокий уровень вирусовыделения в глотке наблюдается в первую неделю с появлением симптомов, достигая наибольшего уровня на 4-й день болезни, что предполагает активную репликацию вируса в верхних дыхательных путях. Продолжительность вирусовыделения после исчезновения симптомов заболевания оценивается в 8-20 дней [28]. Однако обнаружение PHK вируса после выздоровления не означает наличие жизнеспособного вируса [15].

\section{Патогенез COVID-19}

Таким образом, у большинства пациентов COVID-19 протекает в лёгкой и средне-тяжёлой форме, но в некоторых случаях (около 20\%) SARS-CoV-2 вызывает интенсивные воспалительные процессы, называемые «цитокиновым штормом», который может привести к смертельной пневмонии и ОРДС. При этом профили «цитокинового шторма» могут отличаться у разных пациентов [38]. Синдром высвобождения цитокинов это потенциально угрожающий жизни системный воспалительный ответ организма на инфекционный агент, либо лекарственное средство. В данном случае - на SARS-CoV-2. При этом повышается уровень интерлейкина 6 (ИЛ-6), коррелирующего с дыхательной недостаточностью, ОРДС и осложнениями [35]. Повышенные уровни провоспалительных цитокинов могут также свидетельствовать и о развитии вторичного гемофагоцитарного лимфогистиоцитоза [26]. Это опасное для жизни тяжёлое гипервоспаление, вызванное неконтролируемой пролиферацией активизированных лимфоцитов и макрофагов, которые выделяют большое количество воспалительных цитокинов. Воспалительные цитокины представляют собой тип сигнальных молекул, которые выделяются из иммунных клеток, таких как Т-хелперы (Th) и макрофаги. K ним относятся не только интерлейкин-6, но и интерлейкин-1, интерлейкин-8, интерлейкин-12, интерлейкин-18, фактор некроза опухоли альфа (TNF-alpha), гамма-интерферон (IFN-ү) [13]. 


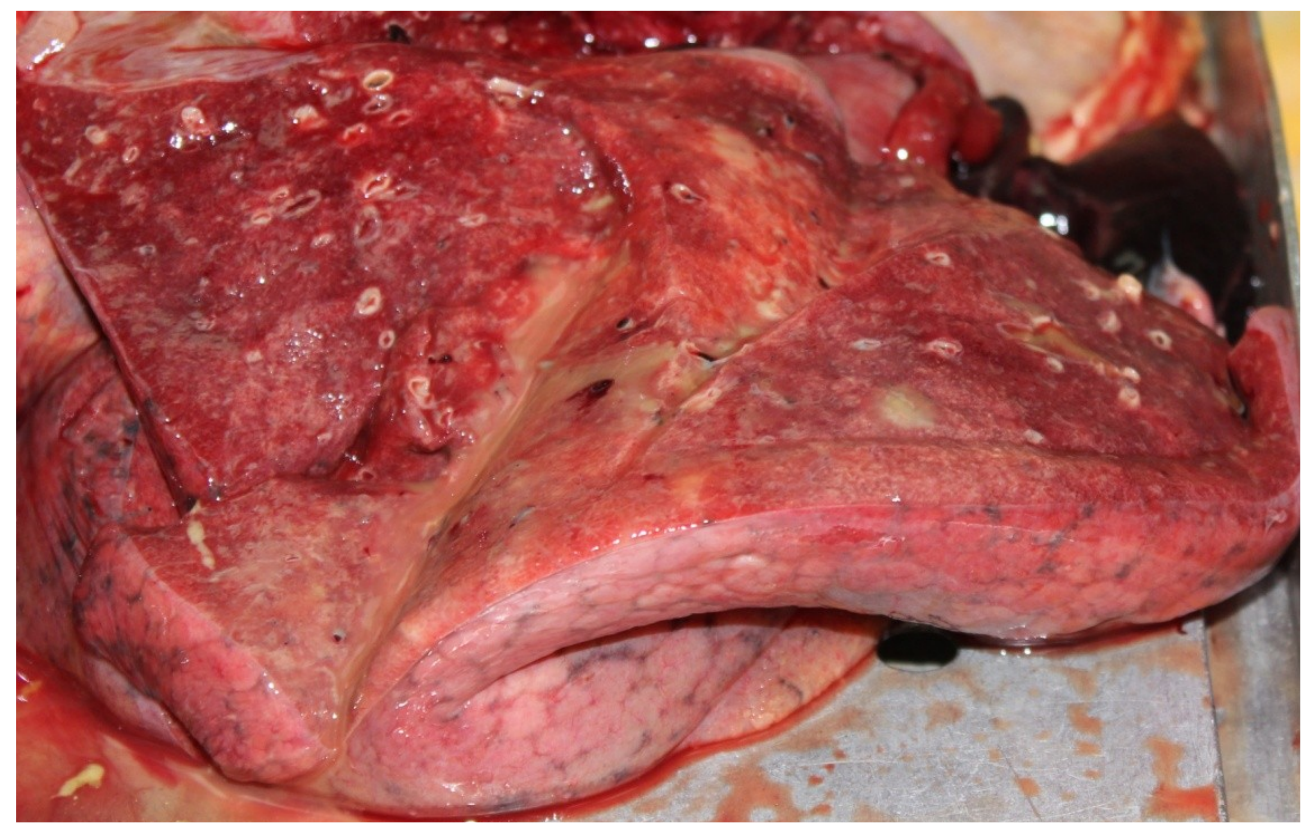

Рисунок 3 Ткань лёгких в норме (макропрепарат)

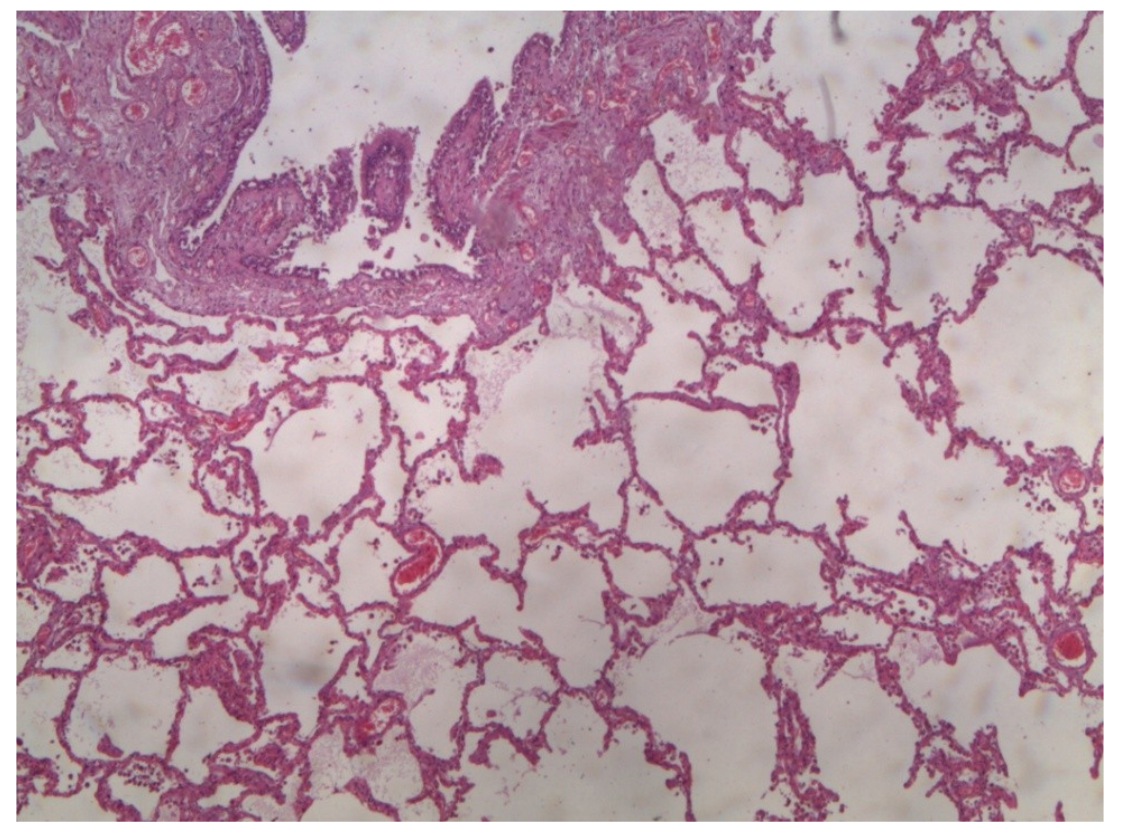

Рисунок 4 Ткань лёгких в норме (микропрепарат)

Лёгкие - это орган, наиболее подверженный воздействию SARS-CoV-2 (рис. 3,4). Вирус, проникая в клетки эпителия верхних дыхательных путей, опускается по слизистой оболочке вниз, получая доступ к клеткам-хозяевам через фермент ACE-2 (ангиотензинпревращающий фермент - 2 типа), который наиболее распространён в альвеолярных клетках лёгких типа II [34]. В лёгких начинается диффузное воспаление, проходящее определённые этапы: от единичных очагов, постепенно сливающихся и захватывающих практически все лёгкие. Процесс обычно носит двусторонний симметричный характер. 
Первоначально поражается лёгочный интерстиций с утолщением межальвеолярных перегородок и частичным заполнением альвеол патологическим субстратом. Происходит уменьшение объёма альвеол за счёт неполного вдоха. Если патологический процесс продолжает развиваться, то постепенно (иногда молниеносно) поражаются все структурные элементы лёгких. В этом процессе выделяют 3 фазы: экссудативную, пролиферативную и фибротическую.

Активированные цитокинами альвеолярные макрофаги и нейтрофильные лейкоциты прикрепляются к эндотелию лёгочных капилляров и освобождают содержимое своих цитоплазматических гранул (протеазы и токсические метаболиты кислорода) [34]. Это приводит к повреждению эндотелия капилляров и эпителия альвеол, нарушая альвеолярно-капиллярный барьер. В результате экссудат проникает в лёгочную паренхиму и альвеолярное воздушное пространство. Нарушается газообмен и возникает гипоксия [26]. Повреждаются альвеолоциты II типа, которые отвечают за образование сурфактанта. При этом происходит спадение альвеол, снижение растяжимости лёгких и внутрилёгочное шунтирование. Кроме того, развивается лёгочная гипертензия в результате внутрисосудистой обструкции тромбами, спазма лёгочных сосудов из-за гипоксии и действия некоторых воспалительных медиаторов (тромбоксан, лейкотриены и эндотелин).

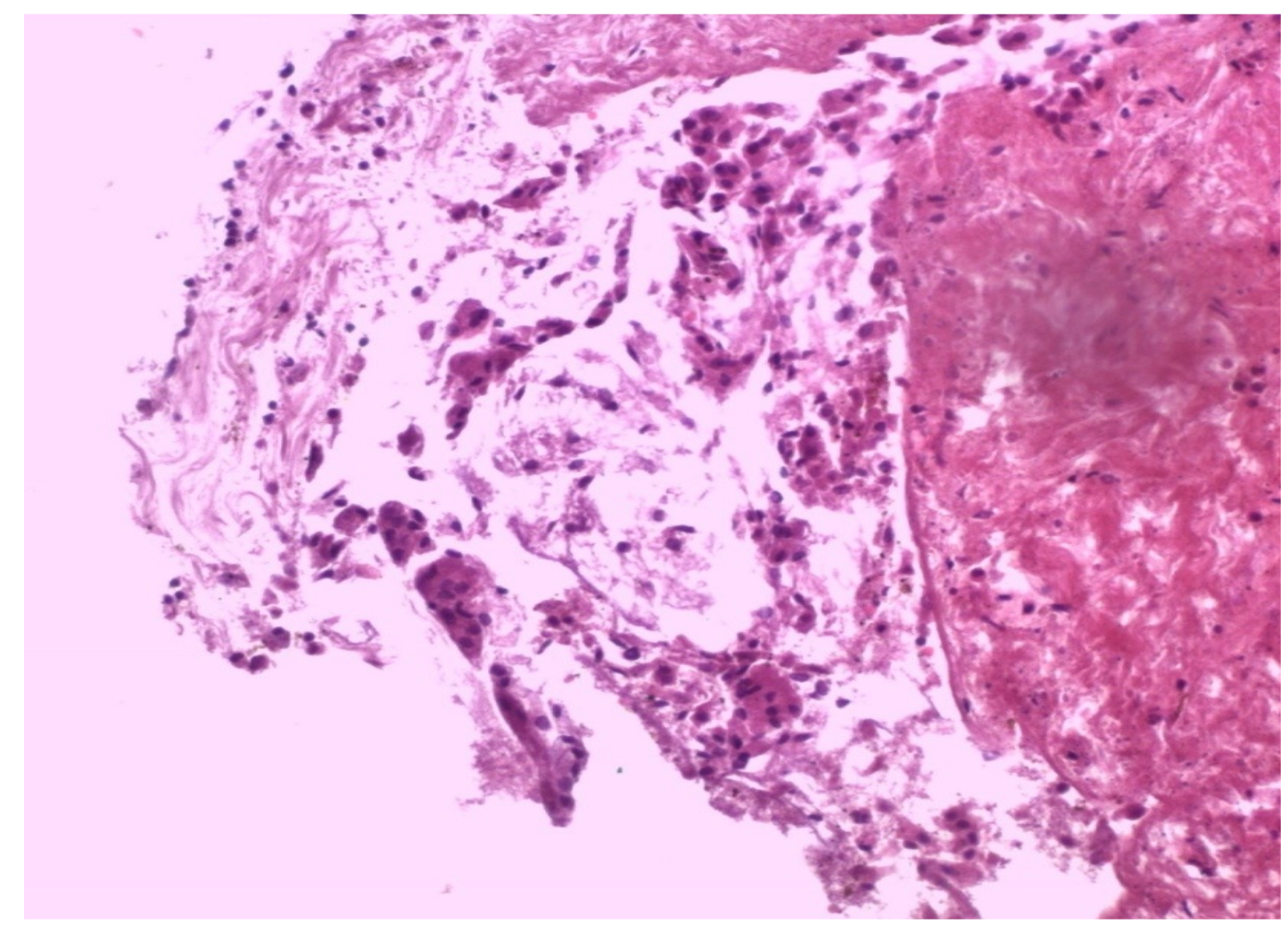




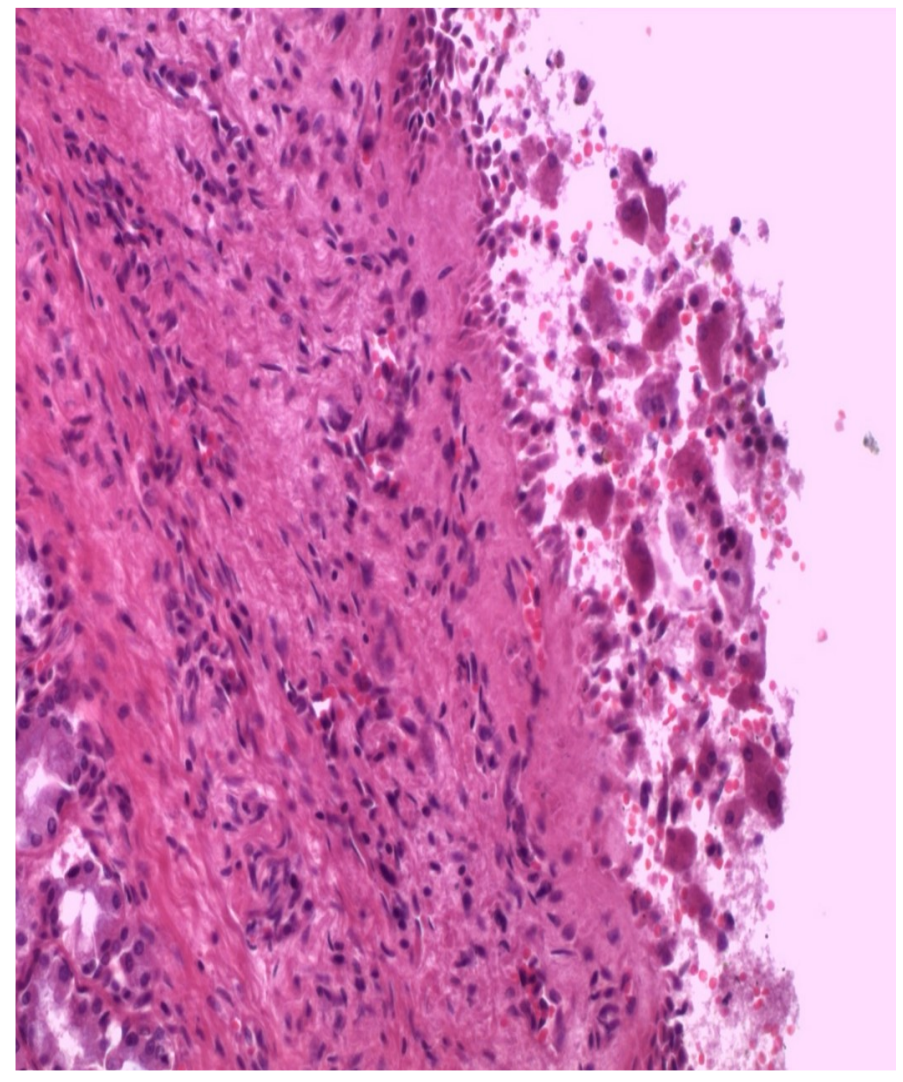

Рисунок 6 Вирусное повреждение трахеи и бронхов

(Рис. 5-6) В трахее и крупных бронхах - эпителий частично слущен, с признаками вирусного повреждения (наличие многоядерных и уродливых клеток), воспалительная инфильтрация отсутствует.

Вследствие прямого вирусного повреждения страдает микроциркуляторное русло с полнокровием капилляров межальвеолярных перегородок, а также ветвей лёгочных артерий и вен со сладжами эритроцитов, свежими фибриновыми и организующимися тромбами; внутрибронхиальные, внутрибронхоальвеолярные и интраальвеолярные кровоизлияния. Возможно формирование геморрагических инфарктов. Данные кровоизлияния являются субстратом для кровохарканья.

Тромбы сосудов важно отличать от тромбэмболов, так как ТЭЛА также характерна для COVID-19. Тромбоз лёгочных артерий может прогрессировать до правых отделов сердца. Описаны тромбозы артерий различных органов с развитием их инфарктов.

Подобные поражения лёгких (рис. 5,6) являются причиной смерти без присоединения бактериальной и микотической суперинфекции [20]. Те процессы, которые происходят в легких и других органах, проиллюстрированы фотографиями макро- и микропрепаратов, которые были выполнены при аутопсиях в условиях ГКБ 15 им. О.М. Филатова (рис. $5,6)$.

В пролиферативную фазу у большинства больных происходит восстановление легких: удаляется экссудат, клеточная инфильтрация. 
Пролифирируют альвеолоциты 2 типа, которые образуют новый сурфактант и дифференцируются в альвеолоциты 1 типа.

Но и в этом периоде у многих больных сохраняется одышка, гипоксемия. У некоторых пациентов процесс переходит в фибротическую фазу.
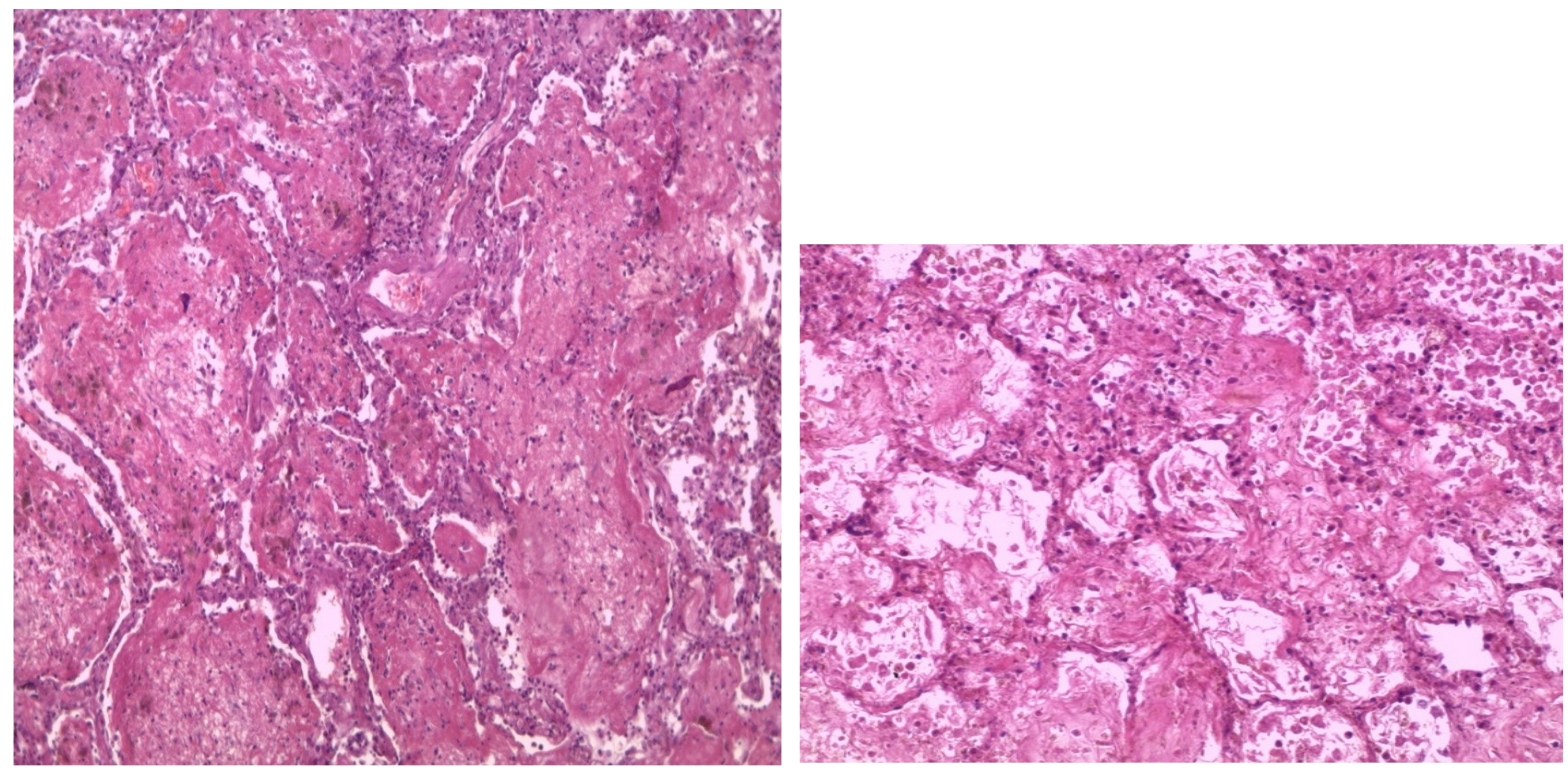

(Pис. 7-8) В просветах альвеол фибрин, разрастания фибробластической ткани, поля облитерирущего бронхиолита и участки рыхлого фиброза с щелевидными структурами, выстланными метаплазированным плоским эпителием, интерстициальное воспаление с утолщением и отеком межальвеолярных перегородок, отек и миксоматоз периваскулярной стромы

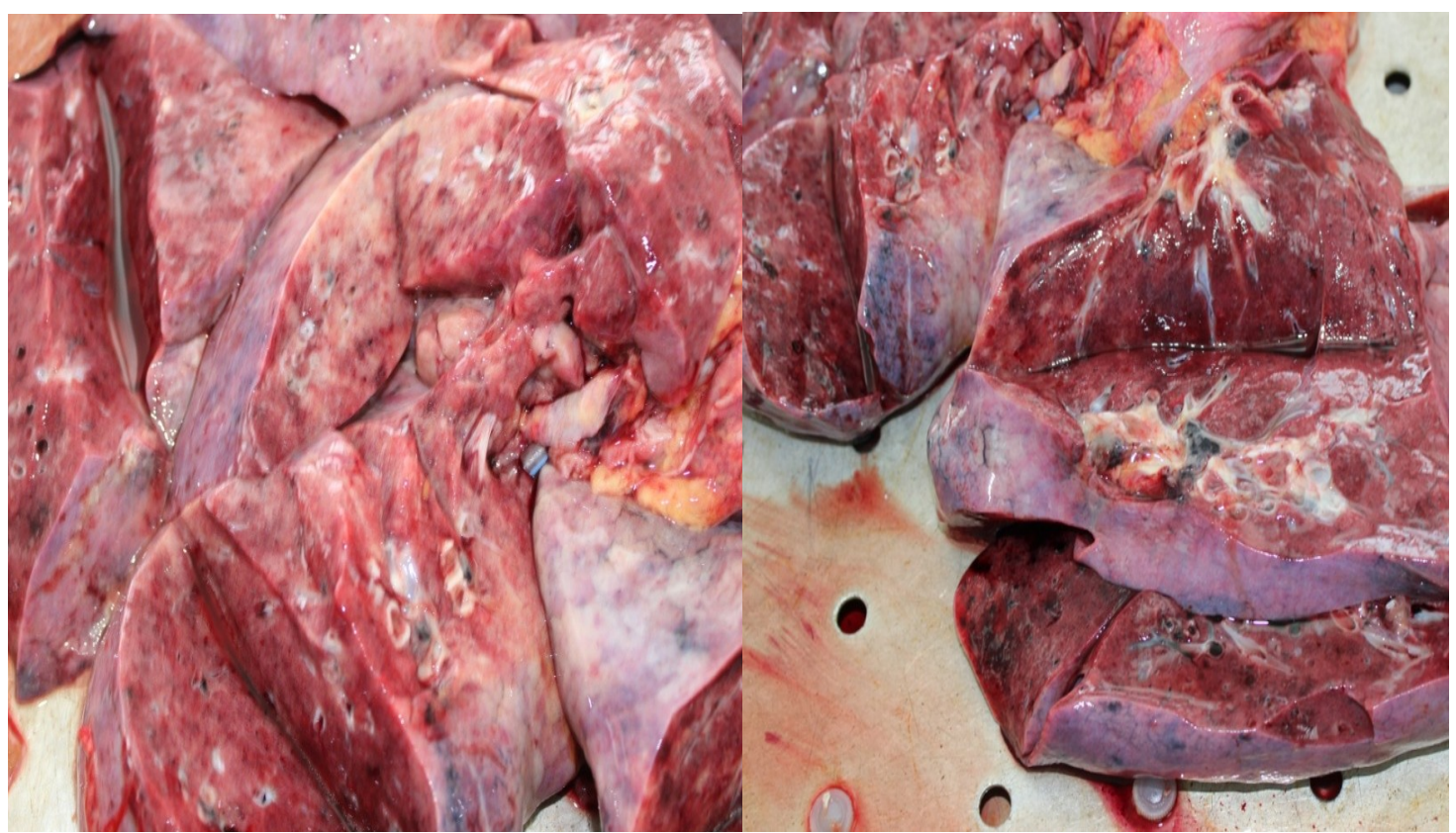

(Рис. 9-10) Фаза организации, разрастания фибробластической ткани, поля облитерирущего бронхиолита и участки рыхлого и плотного фиброза 


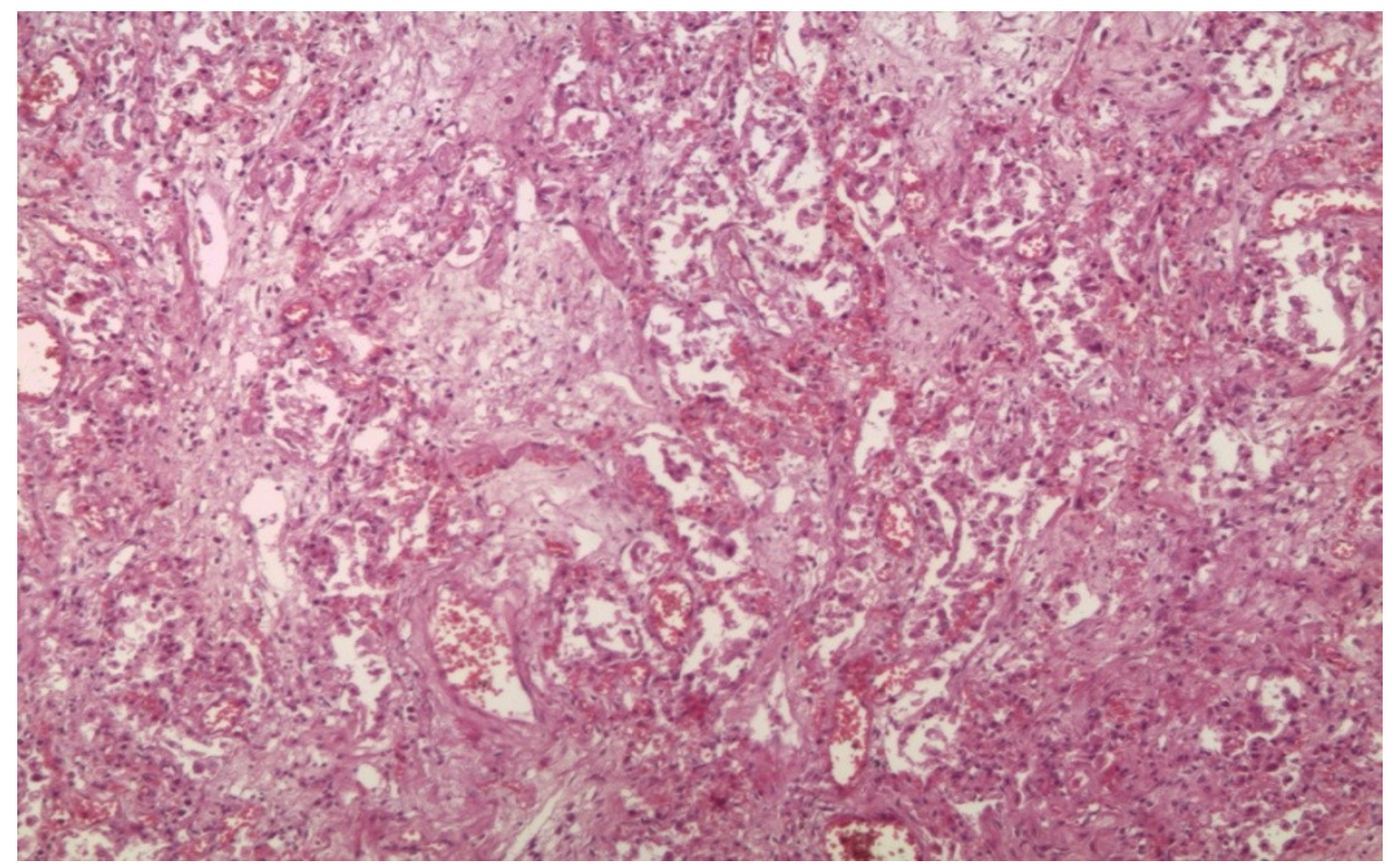

(Рис. 11-12) поля фиброза с щелевидными структурами, выстланными метаплазированным плоским эпителием, разрастание грануляционной ткани с отеком межальвеолярных перегородок, отек и миксоматоз периваскулярной стромы

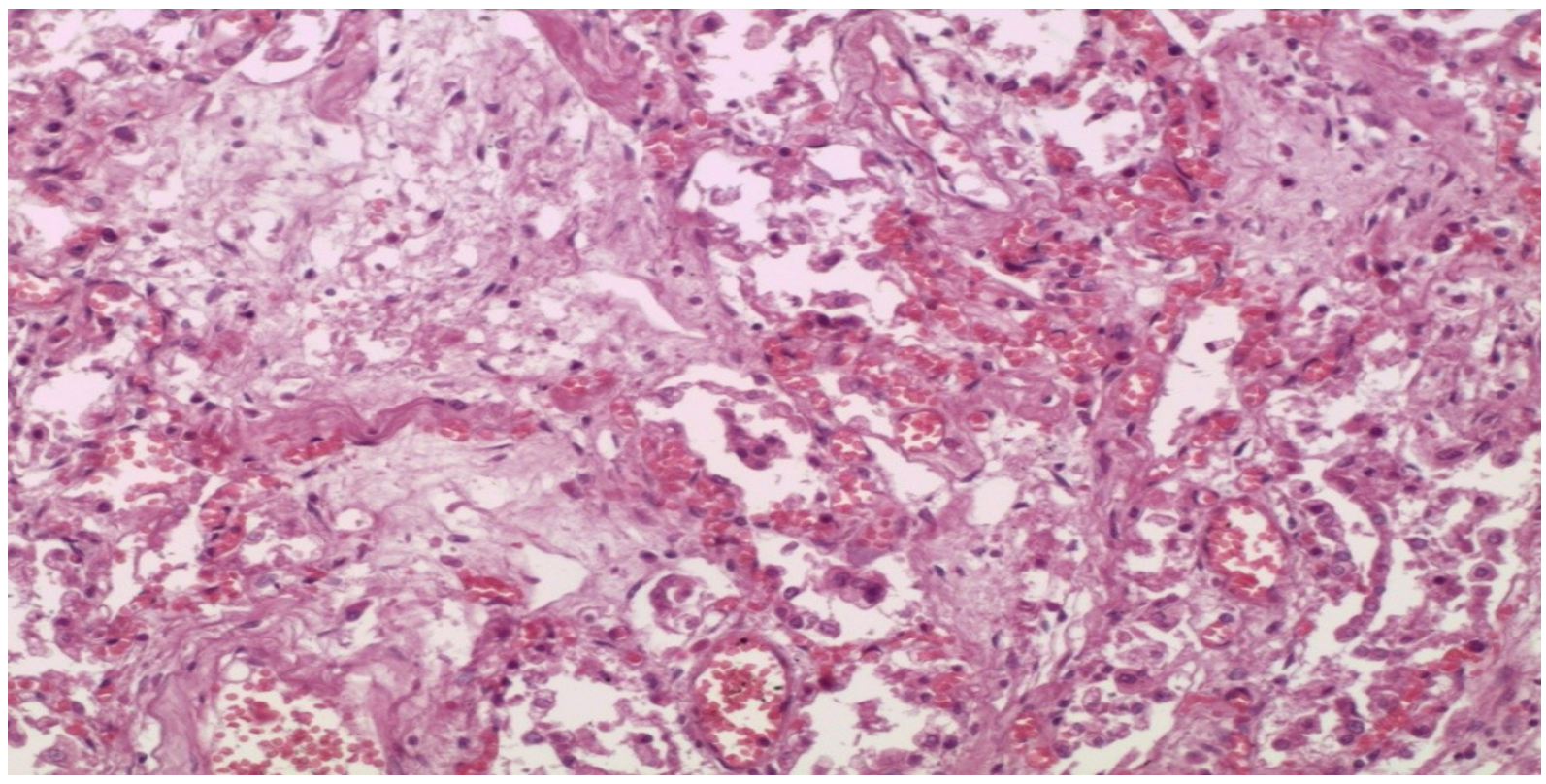

Накопленный в лёгких фибрин подвергается ремоделированию и может вызывать фиброз. 
Но лёгкие, к сожалению, не единственный орган, страдающий при COVID-19. Наблюдая за больными, довольно быстро стало понятно, что в патологический процесс вовлекаются практически все органы и системы.

Причина довольно частого вовлечения органов желудочно-кишечного тракта (ЖКТ) заключается в массивной экспрессии ACE-2 в железистых клетках желудка, в эндотелиальных клетках сосудов и энтероцитов в тонкой кишке, в эпителии прямой кишки. Происходит тяжёлое поражение кишечника с нарушением структур элементов стенки кишечника, разобщением межклеточных взаимодействий. Но кроме этих функциональных расстройств, сопровождающихся клиникой диспепсии, могут быть и некрозы кишечника как следствие мезентериальных тромбозов, так и сегментарных некрозов из-за тромбозов микроциркуляторного русла (рис. 13).

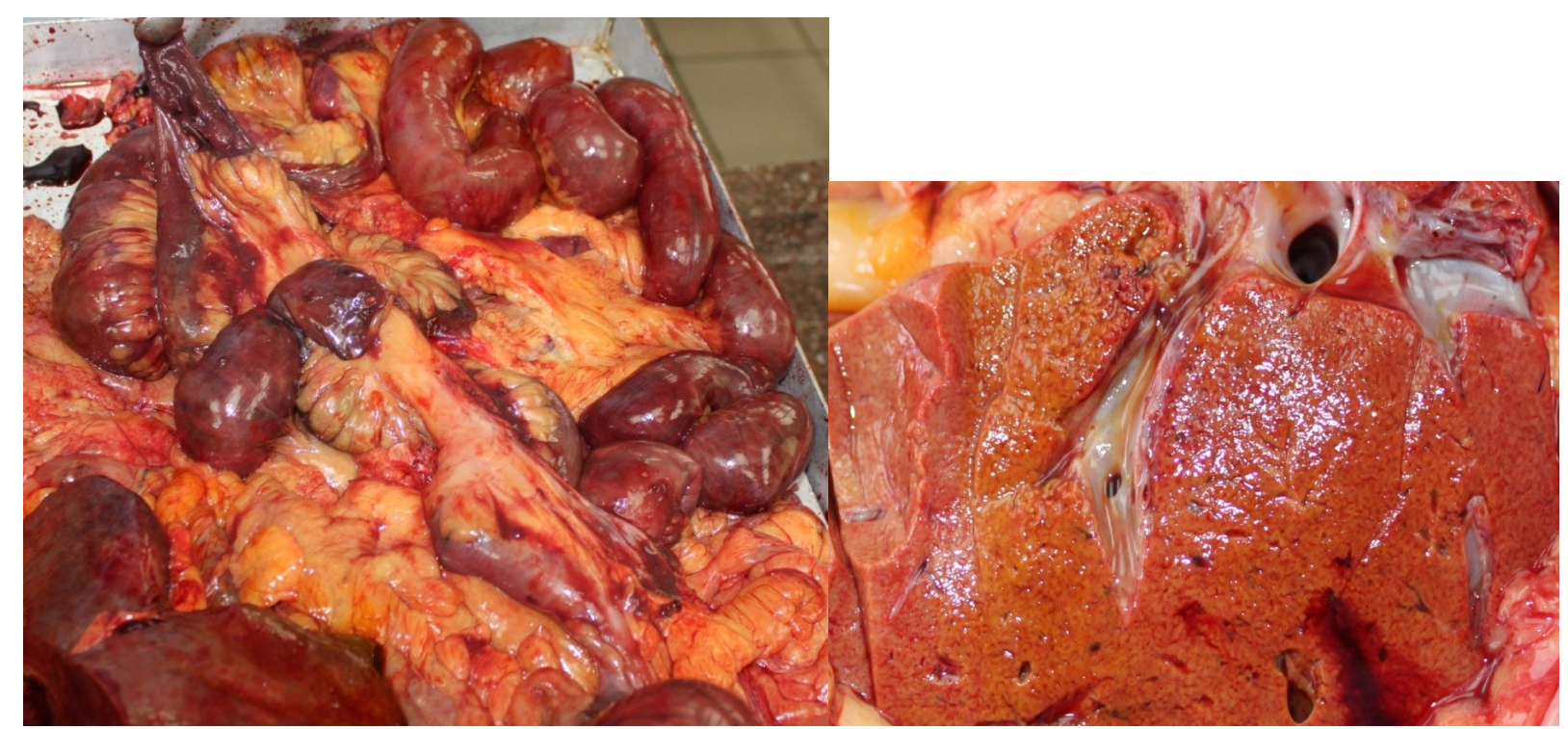

(Рис. 13) Очаговые сегментарные некрозы тонкой кишки

(Рис. 14) Вирусное повреждение печени

Печень является одним из органов-мишеней при COVID-19. При аутопсии выявляется выраженная жировая дистрофия печени, формирующаяся остро (рис. 14).

Следствием тромбозов и тромбэмболий являются обширные инфаркты, вплоть до некрозов печени. Данные процессы приводят к печёночноклеточной недостаточности вплоть до полного отторжения печени (гепатаргия).

Что касается селезёнки и лимфатических узлов, то при гистологическом исследовании констатируется выраженное лимфоидное истощение. Практически весь лимфоидный пул клеток задействован в патологическом иммунном ответе (рис. 15-16). 

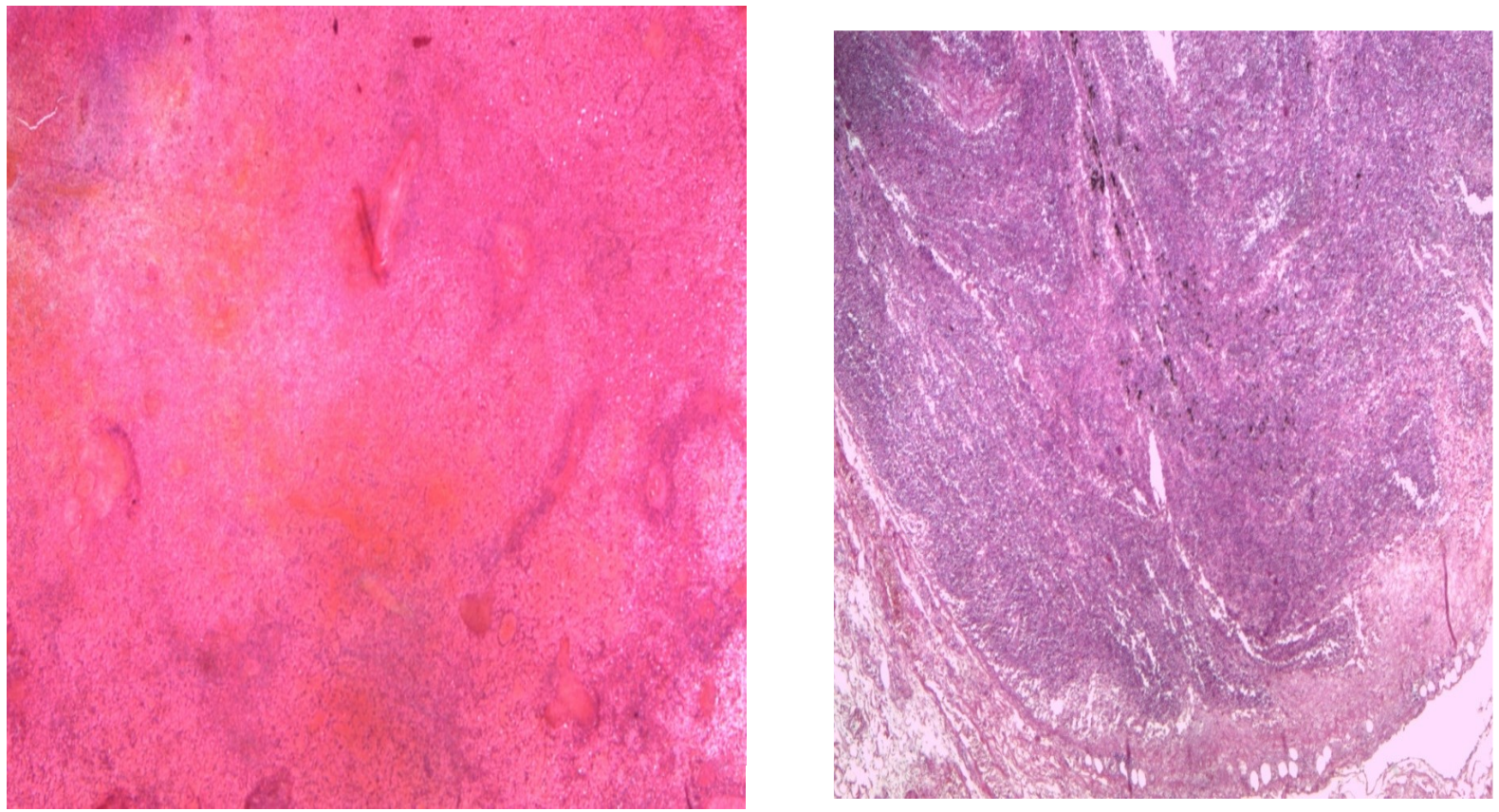

(Рис. 15-16) Селезенка - выраженное истощение лимфоидной ткани, некроз и кровоизлияния в красной пульпе. Лимфатический узел - истощение лимфоидной ткани (гипоплазия лимфоидных фолликулов)

Сердце страдает при COVID-19 существенно и значимо для клинической картины и прогноза заболевания. В миокарде происходят контрактурные повреждения кардиомиоцитов, разволокнение миофибрилл с лимфоидной инфильтрацией (рис. 17,18).

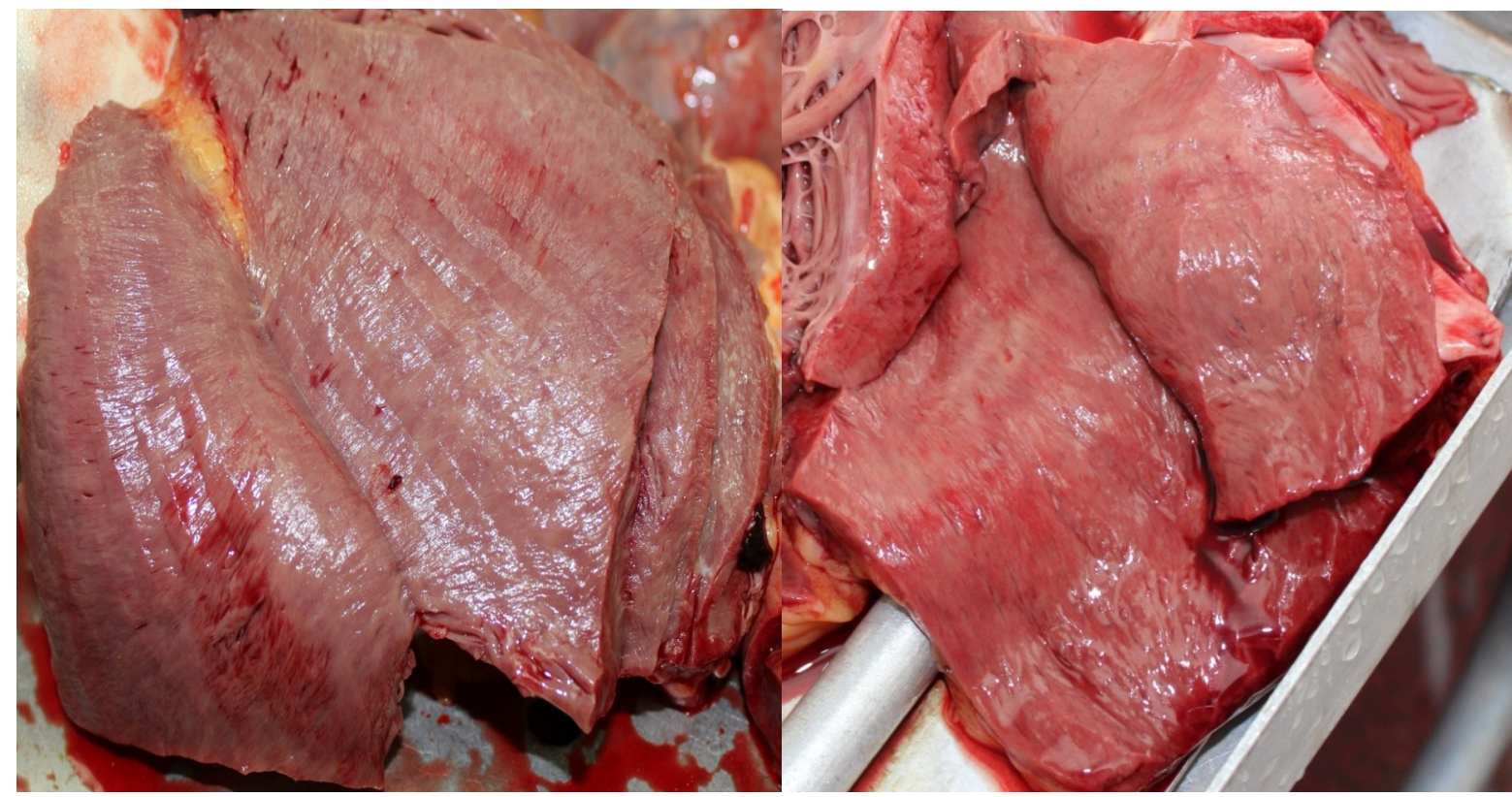

(Рис. 17-18) В миокарде диффузные гипоксические, метаболические и ишемические повреждения, микроангиопатия, мелкоочаговые кровоизлияния. При тромбозах коронарных артерий - очаговые инфаркты миокарда.

У 33\% критических больных диагностируется кардиомиопатия, носящая вторичный характер. Помимо этого, при жизни диагностируются 
инфаркты миокарда как коронарогенного характера (нестабильность атеросклеротической бляшки в связи с воспалением, тромбоз), так и очаговые поражения миокарда 2 типа вследствие непосредственного влияния гипериммунного воспаления на миокард (цитокиновая альтерация с тромбозами микроциркуляторного русла).

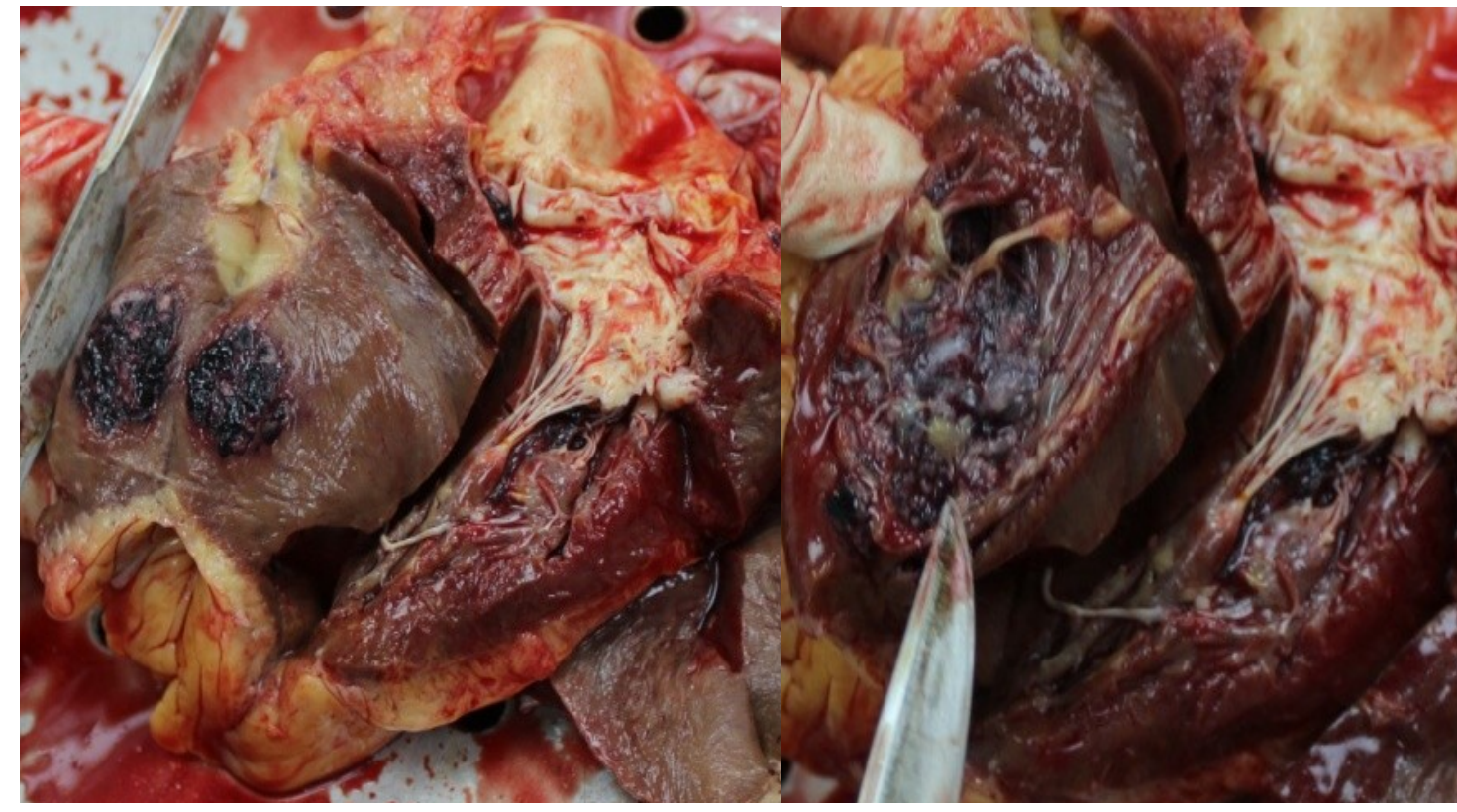

(Рис. 19-20) В миокарде очаговые инфаркты с вторичными обширными кровоизлияниями, фиброзом, внутрижелудочковым тромбообразованием.

Цитокины затрагивают функцию транспортёров и ионных каналов нефронов. В результате происходит изменение активности ионно-калиевых каналов, что изменяет трансэпителиальный транспорт растворённых веществ и воды в почках [13]. Тем самым можно обьяснить часто развивающуюся при данном заболевании гипокалиемию.

SARS-CoV-2 при проникновении в организм человека может поразить головной мозг и центральную нервную систему (ЦНС), о воздействии на которую свидетельствует изменение обоняния на ранних стадиях течения заболевания, а также поведенческие нарушения, периоды возбуждения и, напротив, заторможенности. Возможно развитие сопорозного состояния и комы.

Установлено, что диссеминация SARS-CoV-2 из системного кровотока через пластину решётчатой кости может привести к поражению головного мозга. Гипосмия может свидетельствовать как о поражении центральной нервной системы вышеупомянутым способом, так и путём проникновения через гематоэнцефалический барьер.

Кроме того, были зафиксированы случаи аносмии как в случае отёка слизистой оболочки носа, так и при отсутствии такового (установлено по данным МРТ) [14]. Таким образом, во втором случае имеет место первичное поражение вирусом SARS-CoV-2 непосредственно нервных путей путем 
проникновения в периферические нейроны обонятельного анализатора. Далее вирус по нему поднимается непосредственно в область грушевидной и инфралимбической коры, базальных ганглиев.

В довершении описания характера поражения центральной нервной системы можно добавить, что на фоне развивающейся аноксии при COVID19 возникает отёк мягких мозговых оболочек и вещества головного мозга.
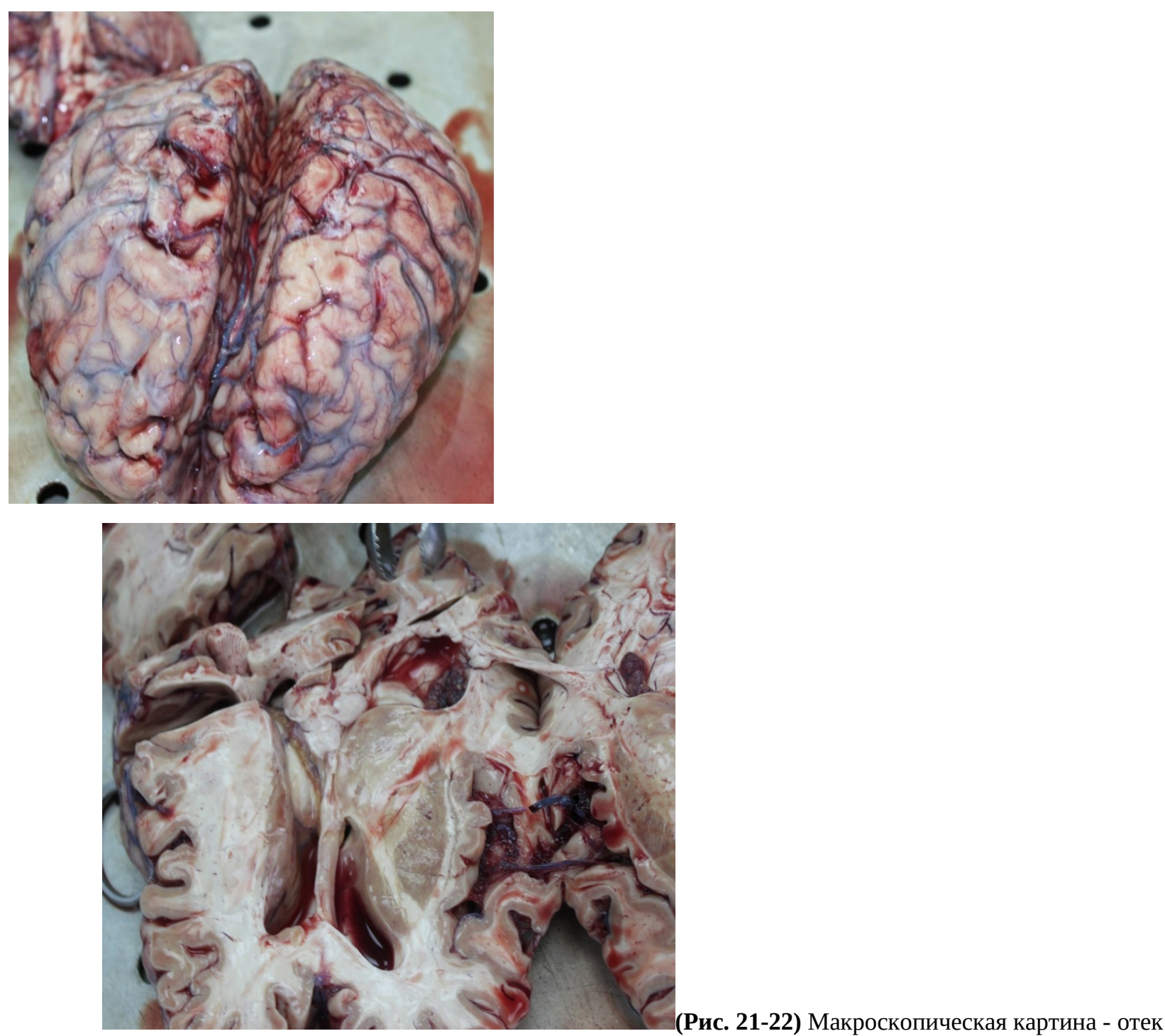
мягких мозговых оболочек и вещества головного мозга, на разрезах области подкорковых ядер и коры с участками розовато-желтого цвета (аноксическая энцефалопатия)

\section{Клиническая картина COVID-19}

Инкубационный период инфекции, вызываемой SARS-CoV-2 составляет 1-14 дней. Заболевание может протекать бессимптомно в лёгкой форме, а также в тяжёлой форме с риском летального исхода [30]. Симптомы развиваются в среднем на 5-6 день с момента заражения. Пациенты с лёгким течением выздоравливают в течение недели [31].

Клинически манифестная форма болезни проявляется в трёх основных видах: 
1) Острая респираторная вирусная инфекция лёгкого течения с симптомами инфекции верхних дыхательных путей (в большинстве случаев) [17].

2) Пневмония без угрозы жизни

3) Тяжёлая пневмония с острым респираторным дистресс-синдромом

В исследовании 1099 пациентов в КНР лихорадка являлась наиболее частым симптомом среди госпитализированных больных. При этом температура тела поднималась далеко не у всех пациентов. Выше $39^{\circ} \mathrm{C}$ лихорадка имела место у 12,3\% пациентов в данном исследовании [21].

В целом же, в клинической картине преобладают [40,4]:

- лихорадка (от 83\% до 99\%)

- кашель (от 59\% до 82\%)

- утомляемость (от 44\% до 70\%)

Беспокоят также [4]:

- потеря аппетита (от 40\% до 84\%)

- одышка (от $31 \%$ до 40\%)

- выделение мокроты (от 28\% до 33\%)

- боли в мышцах (от $11 \%$ до 35\%)

Несколько реже встречаются головная боль, спутанность сознания, насморк, боль в горле, кровохарканье (менее 10\%) [4].

Желудочно-кишечный тракт также вовлекается в процесс: гастроэнтерит наблюдается примерно у 15\% пациентов, при этом у 10\% вообще отсутствовали респираторные симптомы, что приводило к запоздалой диагностике заболевания. Потеря вкуса и обоняния может даже предшествовать появлению респираторных симптомов [27]. 
Возможны также полиморфные сыпи и изменение цвета (гиперемия, синюшность) цвета кожи лица и пальцев рук и ног [2].

В процессе наблюдения за больными мы в нашей клинике так же обратили внимание на полиморфные кожные сыпи (Рис. 23-25).

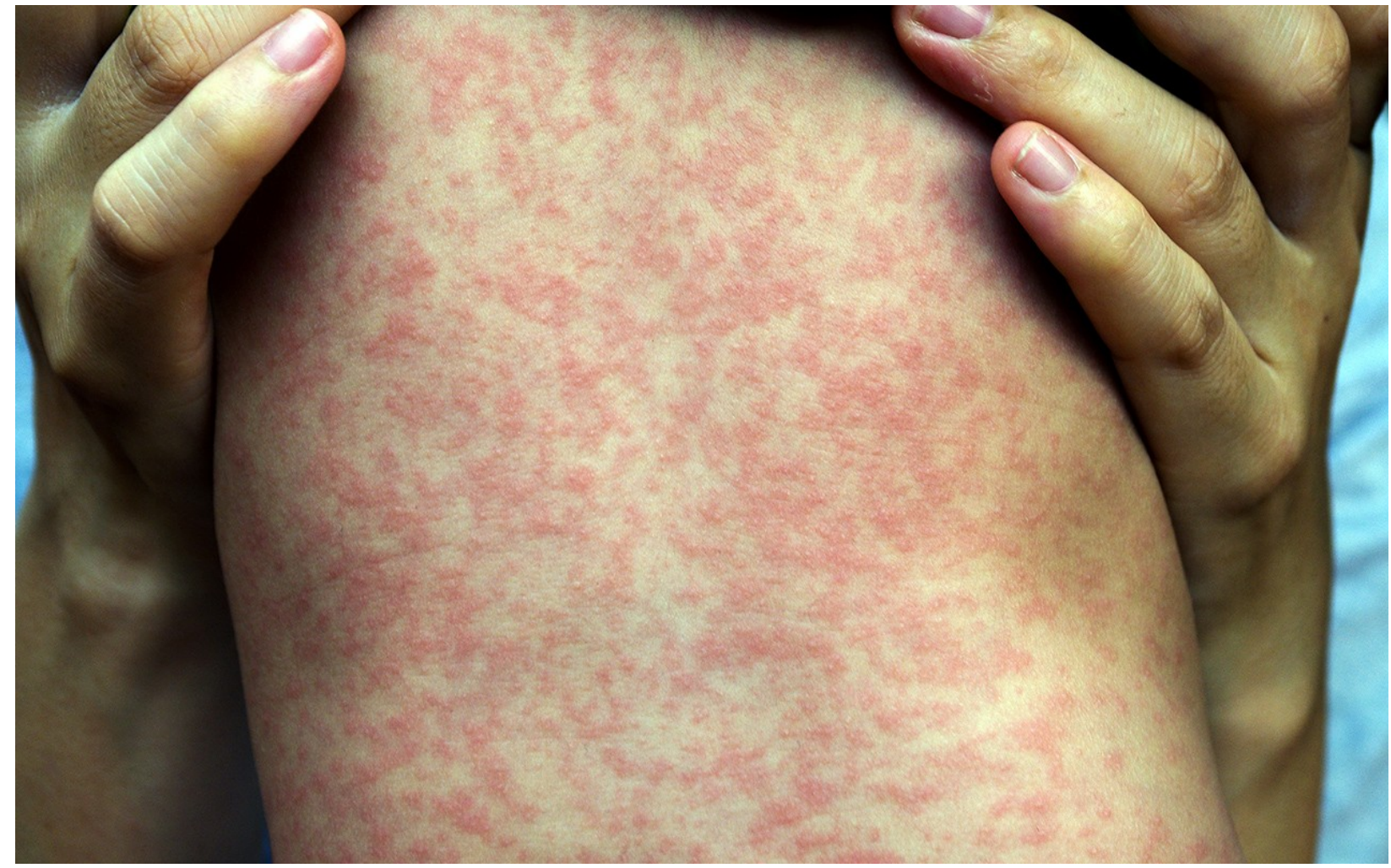

Рисунок 7 Сыпь при поражении вирусом COVID-19

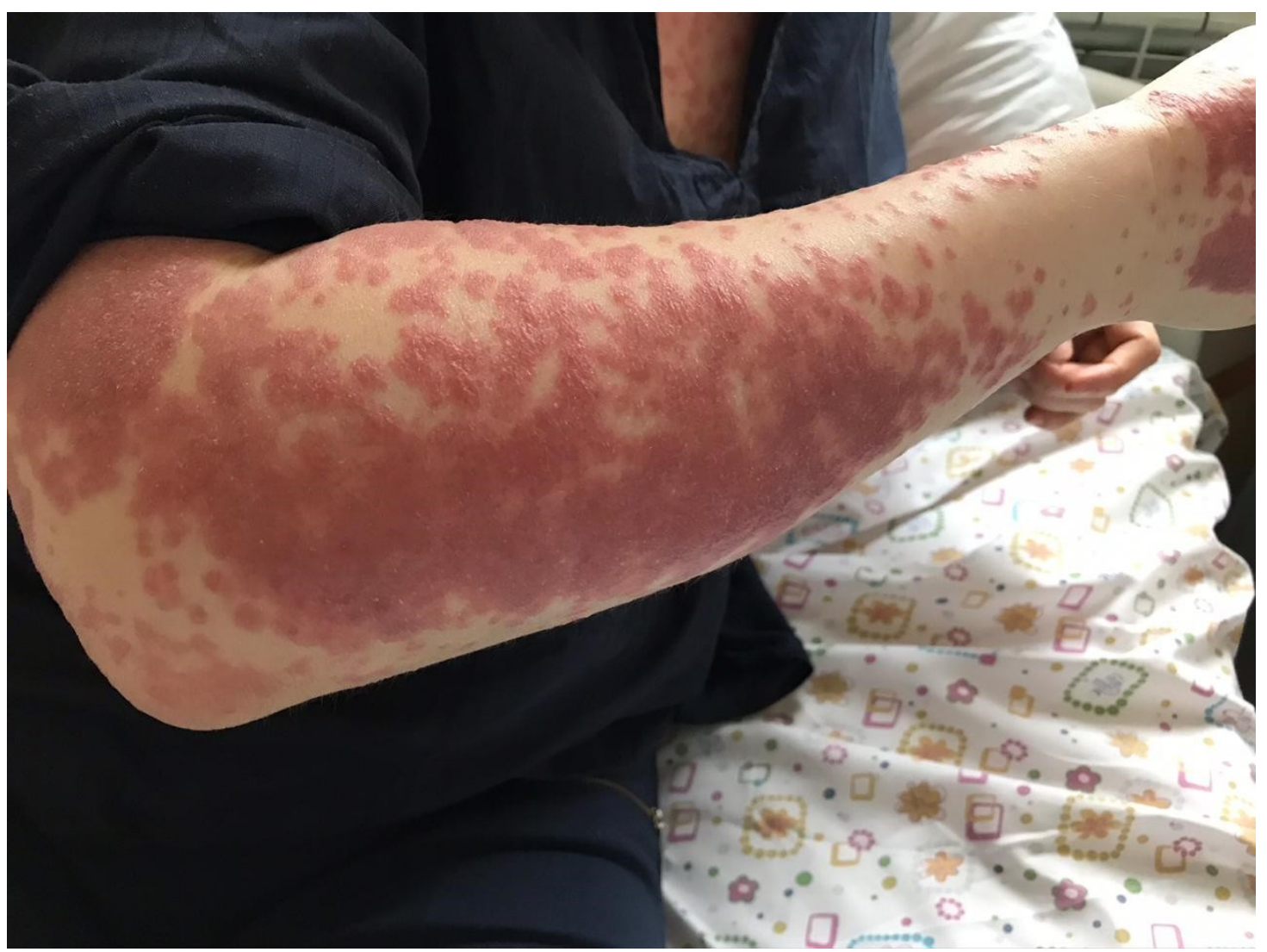


Многообразие кожных проявлений можно условно систематизировать $[10,20]$ :

1. Ангииты кожи инфекционно-аллергического генеза - поражения стенок мелких сосудов дермы циркулирующими иммунными комплексами (ЦИК) в виде депозитов с вирусными антигенами.

2. Папуло-сквамозные сыпи и розовый лишай без «материнской бляшки».

3. Кореподобные сыпи и инфекционные эритемы и инфекционные эритемы.

4. Папуло-везикулярные обширные высыпания на фоне потоотделения.

5. Токсикодермия - связана с лекарственным взаимодействием

6. Крапивница - нередко появляется вместе с первыми симптомами COVID-19, либо связана с лекарственными веществами.

7. Трофические изменения тканей лица - связаны с длительной пронпозицией.

\section{Осложнения COVID-19}

1. От 15\% до 33\% всех осложнений $[4,40]$ приходится на ОРДС.

Больной жалуется на одышку, дискомфорт в грудной клетке. При осмотре наблюдается тахипное, тахикардия, участие вспомогательных мышц в дыхании, цианоз кожного покрова.

Как правило, характерно:

- острое начало

- наличие предрасполагающего фактора

- двусторонние инфильтраты на рентгенограмме легких

- $\mathrm{PaO}_{2} / \mathrm{EiO}_{2}$ менее 200 мм.рт.ст.

- нет признаков левожелудочковой недостаточности, давление заклинивания лёгочной артерии не выше 18 мм.рт.ст.

2. У 8\% больных развивается острая дыхательная недостаточность [36], при которой развивается выраженный дефицит кислорода, что является жизнеугрожающим состоянием. У больных с COVID-19 острая дыхательная недостаточность носит первичный характер вследствие массивного поражения лёгких. Сатурация кислорода снижается ниже 95\%.

3. Одним из грозных осложнений является ДВС-синдром [4,27]. Частота выявления - до 71\% среди погибших людей. Это патологический неспецифический процесс, характеризующийся образованием диссеминированных тромбов (фибринных, эритроцитарных и гиалиновых) в сосудах микроциркуляторного русла в сочетании с несвёртываемостью крови, приво- 
дящей к множественным массивным кровоизлияниям. По-видимому, сам вирус SARS-CoV-2 способен запускать этот сложный процесс, но чаще возникает на инфекционно-септической стадии.

4. От $7 \%$ до $20 \%$ пациентов состояние может осложниться острой сердечной недостаточностью [4,31]. Особенно у людей с коморбидной сердечно-сосудистой патологией. Возможно развитие инфарктов миокарда, миокардитов, кардиомиопатий. Данный синдром усугубляет гипоксию органов и тканей, ацидоз и другие нарушения метаболизма.

5. Вторичная бактериальная инфекция развивается у 6-10\% больных с COVID-19 [27,29]. Необходимо обратить внимание на этот относительно небольшой процент и учитывать данное обстоятельство при назначении антибактериальной терапии (оно не должно быть поголовным). Кроме того, существует ещё целый ряд дополнительных факторов, приводящих к присоединению вторичной инфекции. Чаще это происходит у людей, страдающих хроническими заболеваниями бронхолёгочного аппарата (хронические бронхиты, ХОБЛ, бронхиальная астма), ХСН, сахарным диабетом; у тех, кто длительно находится на стационарном этапе; в реанимационных отделениях и на аппарате ИВЛ. Бактериальная пневмония может развиться на фоне обширного инфаркта лёгкого. У пациента, как правило, начинается вторая волна лихорадочного периода, появляется продуктивный кашель со слизисто-гнойной мокротой, увеличивается уровень лейкоцитов за счёт нейтрофилёза, СРБ и прокальцитонина. На МСКТ появляются зоны консолидации легочной ткани. В таких случаях обязательно микробиологическое исследование мокроты, либо промывных вод бронхов.

6. У довольно большого количества больных (от 14\% до 53\%) развивается острая почечная недостаточность (рис. 26,27) [13].

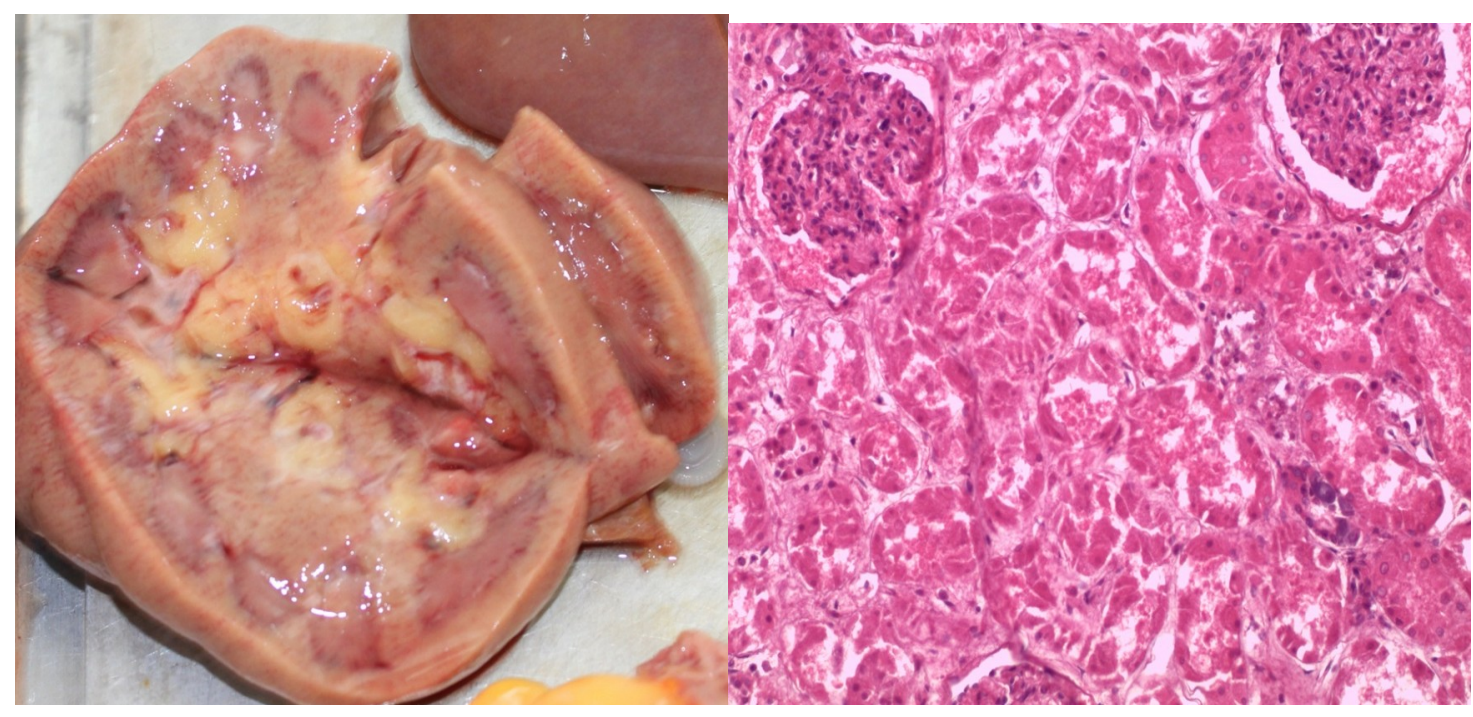

(Рис. 26-27) Диффузный некроз эпителия канальцев почек, отек интерстиция, малокровие коркового вещества, в просвете большей части капсулы клубочков определяется жидкость с белком - осмотический нефроз при острой почечной недостаточности. 
7. Одними из самых грозных осложнений являются сепсис и септический (инфекционно-токсический) шок [13].

8. Тромбоэмболический синдром является причиной нарастания дыхательной недостаточности и нередко летального исхода (рис. 28-30) [15]

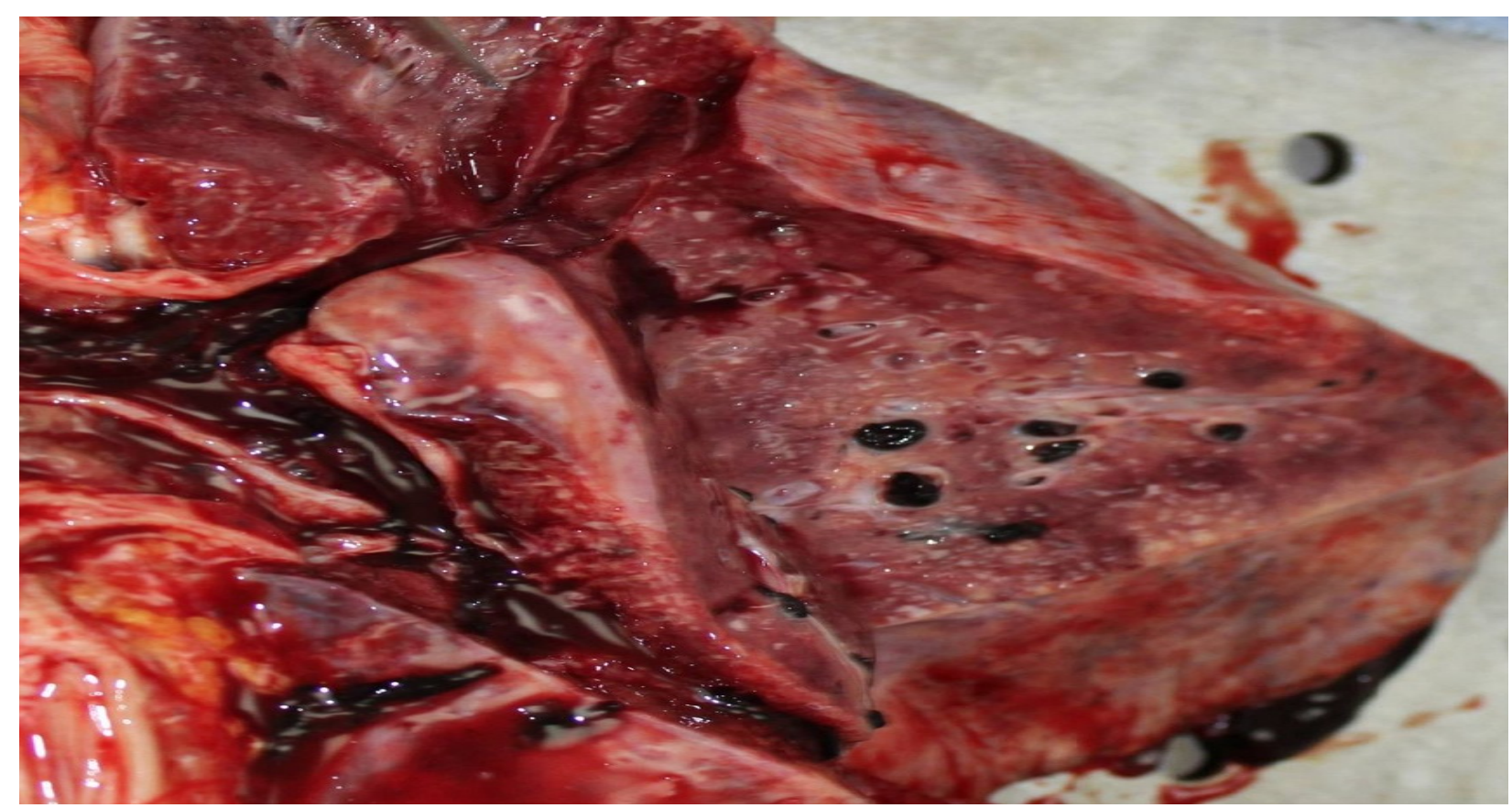

(Рис. 28) Макрофотография свежих фибриновых и организующихся тромбов в ветвях легочной вены и артерии.
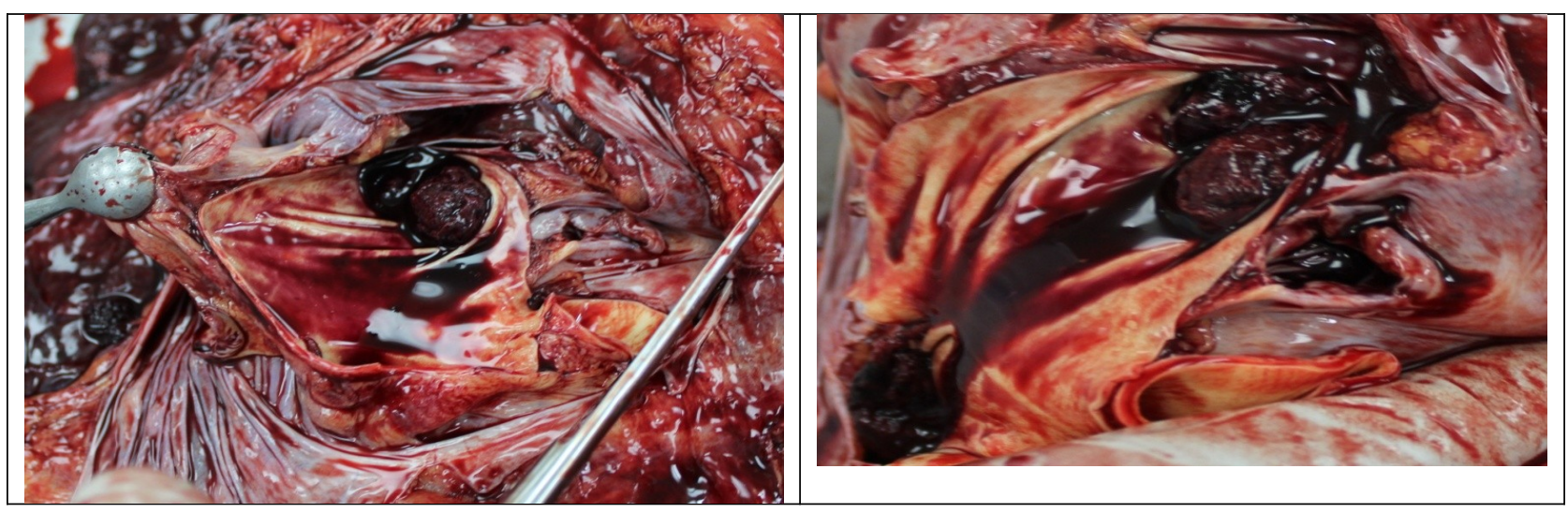

(Рис. 29-30) Макрофотография свежих фибриновых тромбов и тромбоэмболов в ветвях легочной артерии.

Обращает на себя внимание формирование в легочных артериях как пристеночных тромбозов in citu, так и массивных тромбэмболов (рис. 31, 32). 


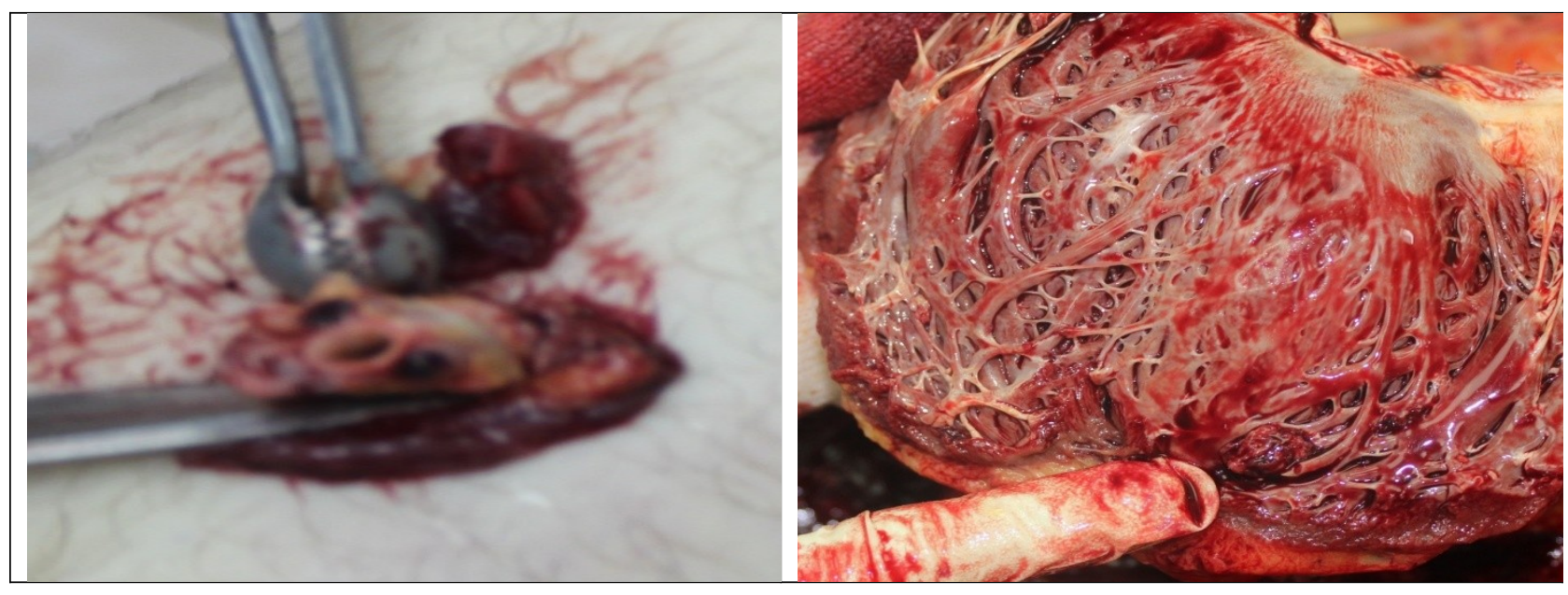

(Рис. 31-32) Тромбы в бедренной вене, межтрабекулярный тромб в левом желудочке сердца.

Тромбэмболический синдром может затронуть также сосуды большого круга кровообращения. Нередки инфаркты селезенки (рис. 33).

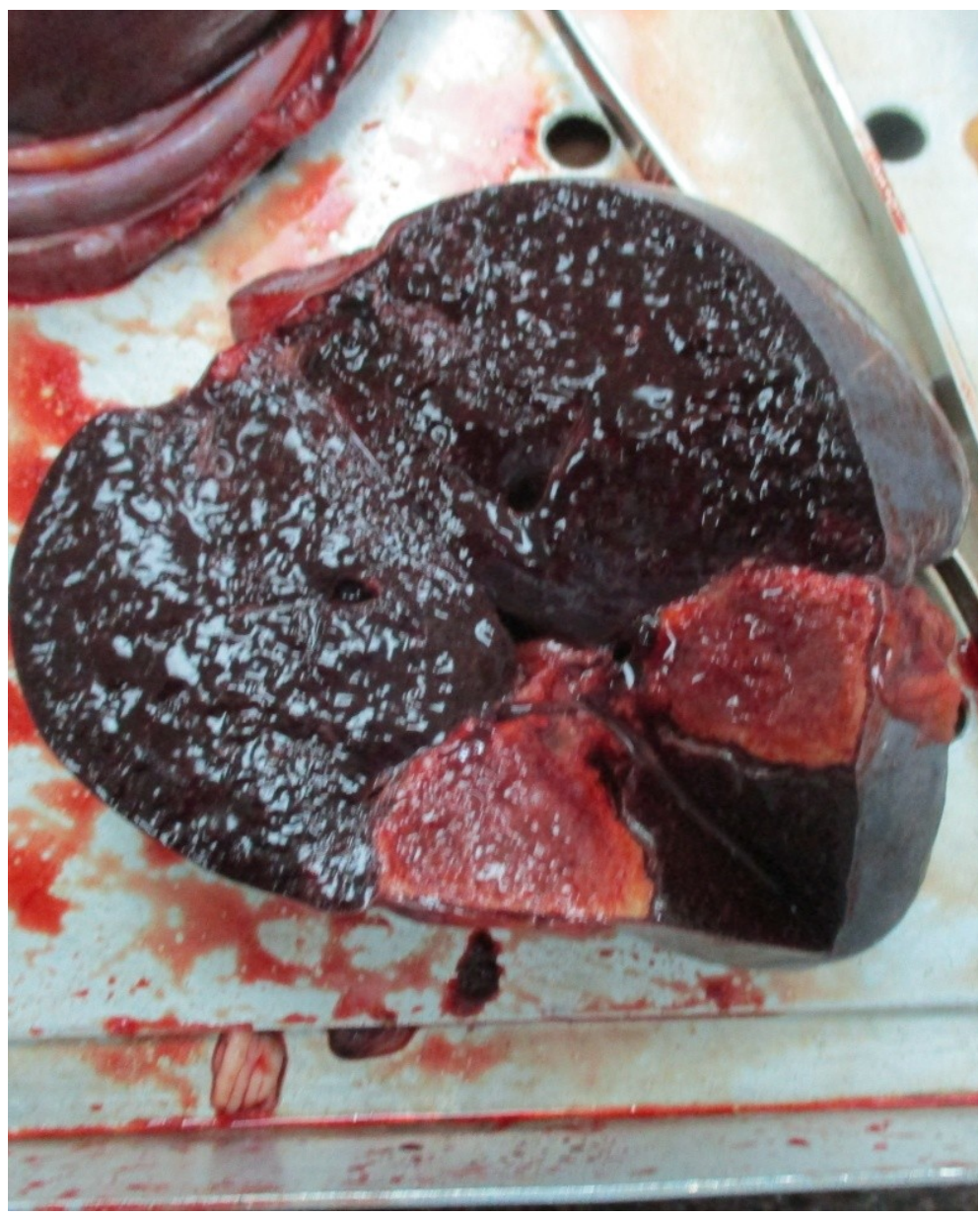

Рис. 33 Инфаркт селезёнки 


\section{Классификация COVID-19}

Согласно рекомендациям Министерства здравоохранения Российской Федерации классификация COVID-19 по степени тяжести включает: лёгкое, средне-тяжёлое, тяжёлое и крайне тяжёлое течение [10].

Как врачи инфекционного госпиталя мы курировали пациентов, в основном, с тяжёлым и крайне тяжёлым течением.

\section{Тяжёлое течение:}

- ЧДД $>30$ в мин.

- $\mathrm{SpO}_{2} \leq 93 \%$

- $\mathrm{PaO}_{2} / \mathrm{FiO}_{2} \leq 300$ мм.рт.ст.

- снижение уровня сознания

- нестабильная гемодинамика АД < 90/60 мм.рт.ст.

- $\mathrm{KT} \mathrm{3-4} \mathrm{ст.} \mathrm{с} \mathrm{характерными} \mathrm{для} \mathrm{вирусного} \mathrm{поражения} \mathrm{изменениями}$

- лактат артериальной крови $>2$ ммоль/л

- qSOFA > 2 балла

\section{Крайне тяжёлое течение:}

- ОДН с необходимостью респираторной поддержки (ИВЛ)

- Септический шок

- Полиорганная недостаточность

- Изменения на КТ критической степени КТ-4 или картина ОРДС

- qSOFA > 2 балла

\section{Диагностика коронавирусной инфекции}

Подозрительным на COVID-19 может считаться клинический случай характерной клинической картины без эпидемиологического подтверждения.

Вероятный диагноз- это наличие клинической картины и определённого эпидемиологического анамнеза, либо данных компьютерной томографии лёгких вне зависимости от результатов однократного лабораторного исследования на наличие рибонуклеиновой кислоты (РНК) SARS-CoV-2 и эпидемиологического анамнеза.

Подтверждённым диагноз можно считать при положительном результате лабораторного исследования на наличие PHK SARS-CoV-2 с применением методов амплификации нуклеиновых кислот вне зависимости от клинических проявлений. 
Пациенту с коронавирусной инфекцией, вызванной SARS-CoV-2 проводится комплекс клинического обследования, включающий сбор анамнеза, физикальных данных, исследование диагностического материала, пульсоксиметрию.

Помимо жалоб, подробно собирается анамнез и эпидемиологический анамнез.

Физикальное обследование включает оценку всех органов и систем. Особое внимание уделяется слизистым оболочкам верхних дыхательных путей, термометрии, оценку уровня сознания, измерению частоты сердечных сокращений, артериального давления, частоты дыхательных движений.

Обязательно проводят пульсоксиметрию с измерением $\mathrm{SpO}_{2}$ для выявления дыхательной недостаточности и оценки выраженности гипоксемии.

\section{Лабораторная диагностика этиологическая}

1. Выявление PHK SARS-CoV-2 с применением методов амплификации нуклеиновых кислот.

2. Выявление иммуноглобулинов класса М и класса G к SARS-CoV-2.

\section{Прогностические лабораторные маркёры [4,27]}

Уровень лейкоцитов у большинства больных нормальный, у одной трети обнаруживается лейкопения. Наиболее частым и характерным признаком является лимфопения. Тромбоцитопения носит умеренный характер, но более отчётливая среди группы с тяжёлым течением и в последствии умерших от COVID-19.

При COVID-19 клиническое значение имеет повышение уровня Ддимера, протромбинового времени и фибриногена. Увеличение Д-димера в 34 раза имеет прогностически неблагоприятное значение.

Уровень С-реактивного белка (СРБ) коррелирует с тяжестью течения, распространенностью воспалительной инфильтрации и прогнозом при пневмонии. Увеличиваются также СОЭ, интерлейкин-6, интерлейкин-10, $\Phi H O-\alpha$.

Снижается количество CD-4 и CD-8 T-клеток, ассоциированных с лимфопенией. Отмечено увеличение острофазового белка ферритина при неблагоприятном течении заболевания.

Лабораторными признаками «цитокинового шторма» и ОРДС могут быть внезапное нарастание клинических проявлений через 1-2 недели от момента начала заболевания, сохраняющаяся или вновь появившаяся 
фебрильная лихорадка (вторая волна) выраженная лимфопения в общем анализе крови (Т- и В-лимфоцитов), значительное повышение СРБ более 75 мг/л, интерстициальное поражение лёгких.

При развитии ОРДС каждые 48-72 часа необходимо определять уровень интерлейкина-6, Д-димера, ферритина, фибриногена, С-реактивного белка, триглицеридов, ЛДГ.

Маркёром присоединения вторичной инфекции является уровень прокальцитонина. Если его значение превышает 0,5 мкг/л - вероятна бактериальная инфекция. При последующем повышении - вероятно развитие сепсиса.

При ОРДС, септическом состоянии высока вероятность синдрома полиорганной недостаточности $(\mathrm{CПОН})$. О наличии данного синдрома свидетельствуют отклонения биохимических показателей, отражающих дисфункцию тех или иных внутренних органов.

При развитии сердечно-сосудистых осложнений при COVID-19 повышается уровень МВ-фракции креатинкиназы, высокочувствительного тропонина и мозгового натрий-уретического пептида (NT-proBNP). При повышении нормального уровня данных показателей необходимо дифференцировать тяжёлую форму миокардита, острого инфаркта миокарда I типа (коронарогенного вследствие нестабильности атеросклеротической бляшки и тромбоза) и II типа, как следствие повреждающего действия системного гипериммунного ответа («цитокинового шторма»).

\section{Инструментальная диагностика}

Важнейшим методом оценки гипоксемии является пульсоксиметрия с измерением сатурации крови кислородом $\left(\mathrm{SpO}_{2}\right)$ [37].

Пульсоксиметри́я (оксигемометрия,

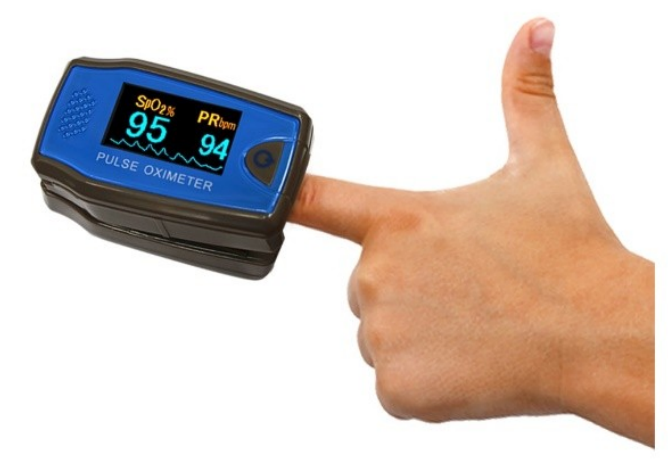
гемоксиметрия) - неинвазивный метод определения степени насыщения крови кислородом. В основе метода лежит спектрофотометрический способ определения насыщения крови кислородом. Проводится с помощью пульсоксиметра (рис. 34).

По величине снижения сатурации крови кислородом определяют степень необходимой респираторной поддержки. Пациентам с признаками ОДН 
рекомендуется исследование газов артериальной крови с определением $\mathrm{PaO}_{2}$, $\mathrm{PaCO}_{2}, \mathrm{pH}$, бикарбонатов, лактата.

К методам лучевой диагностики органов грудной клетки (ОГК) с предполагаемой/установленной COVID-19 пневмонией относят:

- Обзорную рентгенографию лёгких (РГ)

- Компьютерную томографию лёгких (КТ)

- Ультразвуковое исследование лёгких и плевральных полостей (УЗИ)

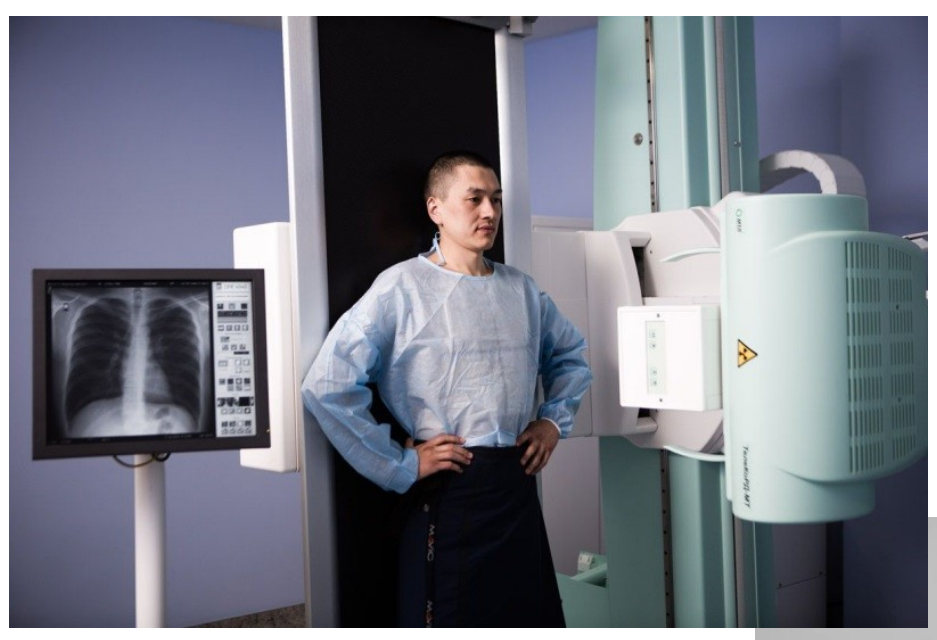

Стандартная РГ (рис. 35) имеет низкую чувствительность в выявлении начальных изменений и не может применяться для ранней диагностики. Метод позволяет уверенно выявлять тяжёлые формы пневмоний и отёк лёгких (ОРДС).

Рис. 35 Обзорная рентгенография лёгких

КТ (рис. 36) имеет высокую чувствительность в выявлении изменений в лёгких, характерных для COVID-19. KT позволяет выявить характерные изменения в лёгких у пациентов с COVID-19 ещё до положительных лабораторных тестов методом полимеразной

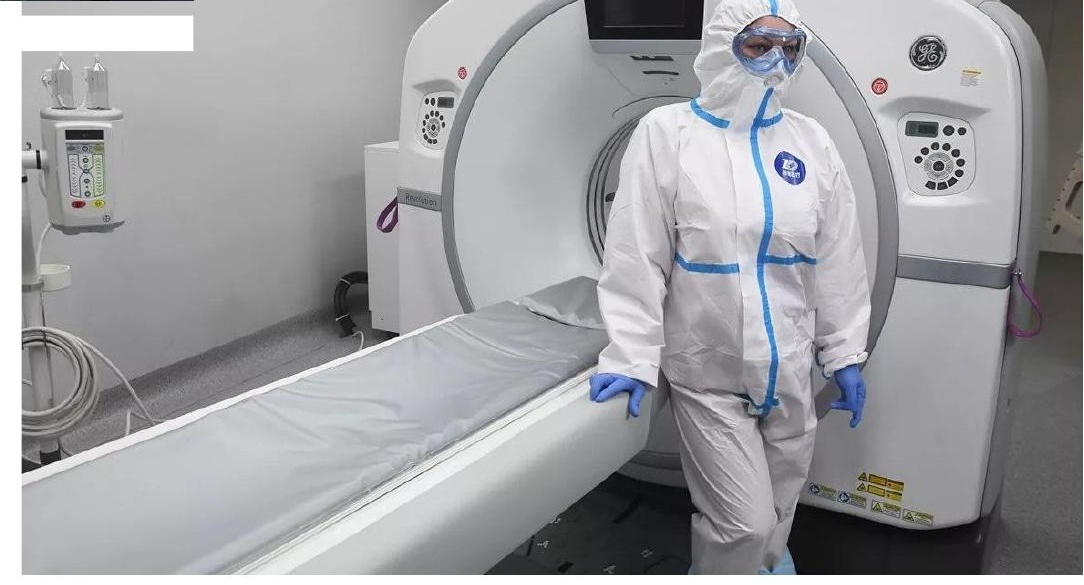

цепной реакции (ПЦР).

В то же время выявление изменений на КТ при бессимптомных и лёгких формах заболевания никак не влияет на тактику ведения пациентов, которые не нуждаются в госпитализации. Поэтому массовое применение компьютерной томографии для скрининга асимптомных и лёгких форм болезни не рекомендуется. 
Основные KT-паттерны при COVID-19 [3,10]

Распределение: билатерально, преобладают в базальных и субплевральных отделах.

1) Уплотнения лёгочной ткани по типу «матового стекла»

2) Наличие участков «матового стекла» с ретикулярными изменениями (утолщенные междольковые перегородки)

3) Участки консолидации

4) Синдром «обратного гало» (организующаяся пневмония)

5) Увеличение диаметра сосудов в уплотненной лёгочной ткани

6) Тракционные бронхоэктазы

\section{Лучевые стадии развития коронавирусной инфекции:}

1) Ранняя стадия (0-4 дни). Данные компьютерные томограммы без признаков патологических изменений лёгких, или минимальные изменения лёгочной ткани по типу «матового стекла» в субплевральных отделах (более $50 \%$ больных не имеют патологических изменений в лёгких в первые два дня заболевания).

2) Стадия прогрессирования заболевания (4-8 дни). Характеризуется увеличением протяжённости участков уплотнения лёгочной ткани, появлением на их фоне ретикулярных изменений по типу «лоскутного одеяла» или «булыжной мостовой».

3) Стадия максимальных проявлений заболевания. Участки уплотнения лёгочной ткани по типу «матового стекла». Сочетание «матового стекла» и ретикулярных изменений с формированием КTкартины «лоскутного одеяла». Появление участков консолидации лёгочной ткани, зачастую отражающих присоединение бактериальной инфекции.

4) Регресс заболевания, стадия последствий. 


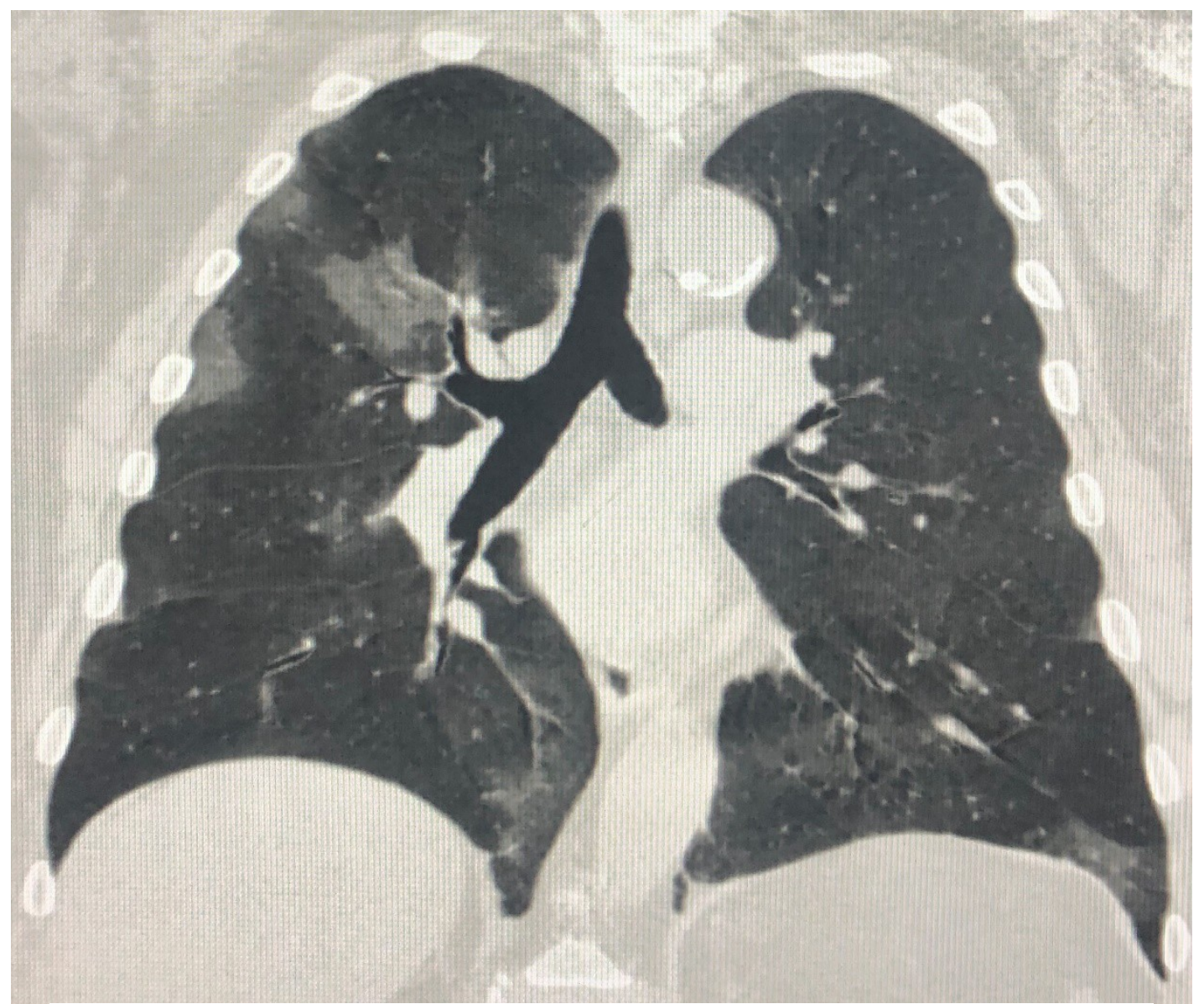

Рис. 37 КТ лёгких при поступлении в стационар (К., 53 лет)

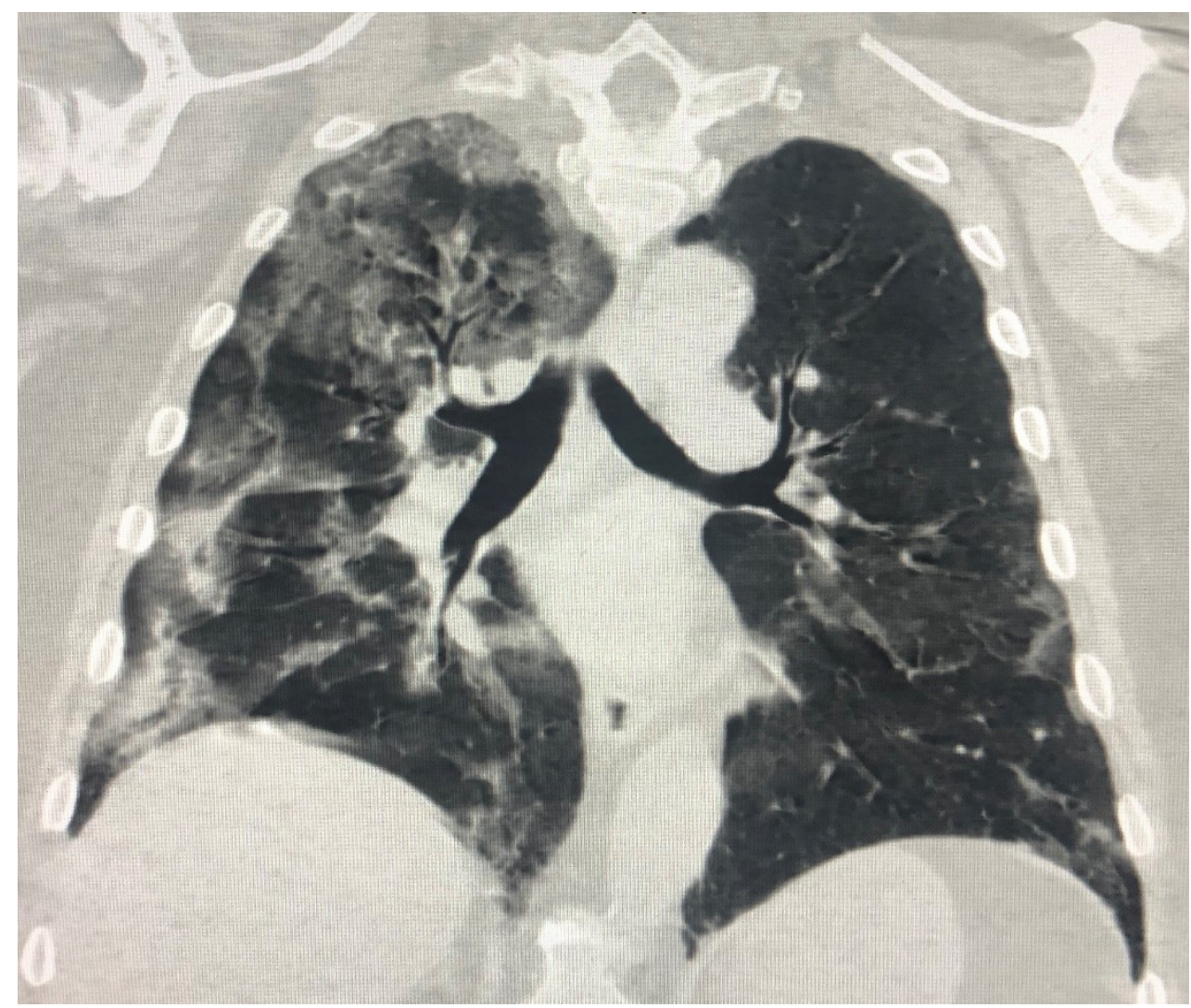

Рис. 38 КТ легких пациента через 5 дней (К., 53 лет) 


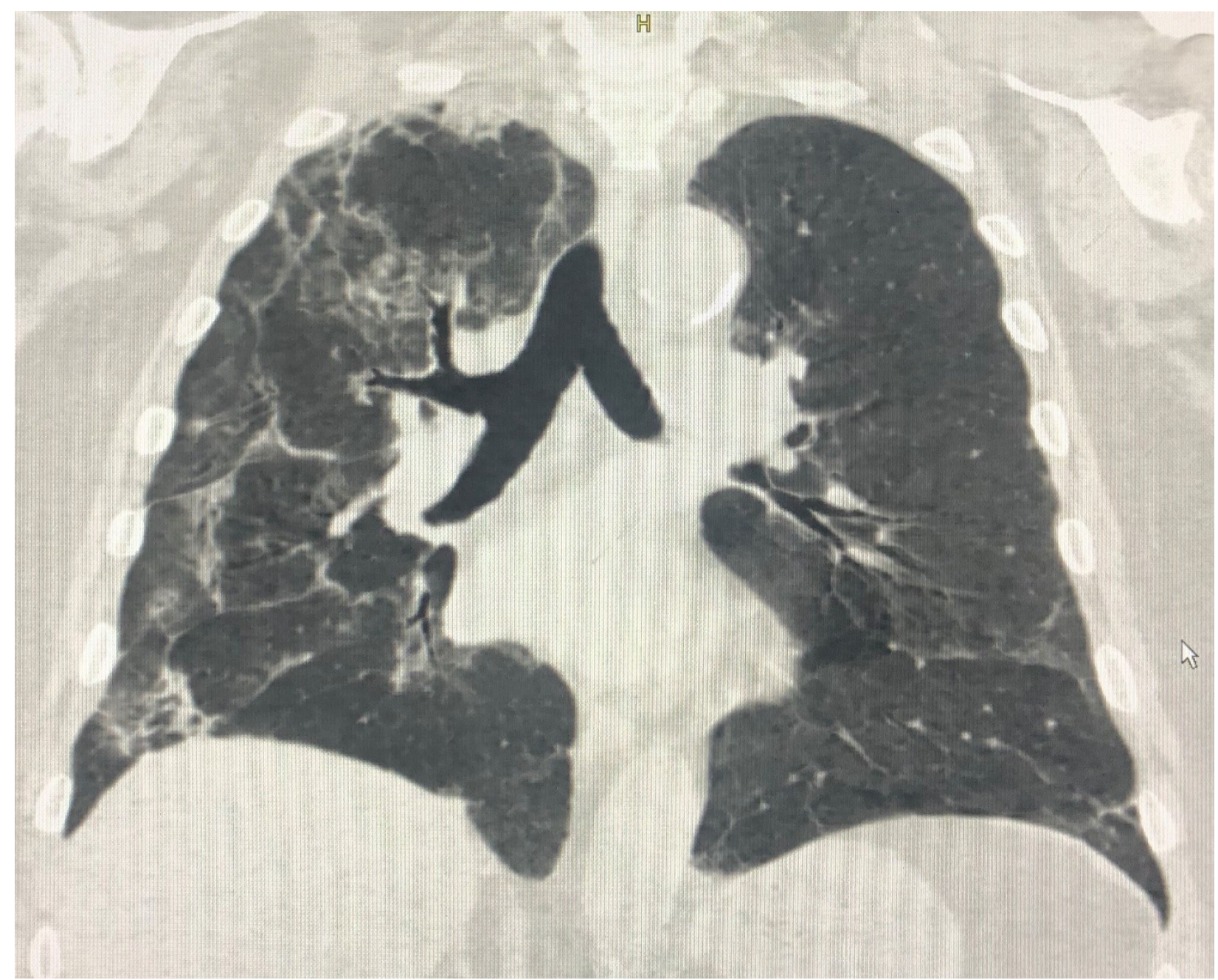

Рис. 39 КТ легких пациента через 10 дней (К., 53 лет). Ретикулярные элементы «булыжная мостовая» 


\section{Алгоритм лучевой диагностики}

с учётом клинической вероятности COVID-19 (таблица 1)

Таблица 1. Разновидность КТ-признаков заболевания (рис. 40-43)

\begin{tabular}{|c|c|c|}
\hline КТ паттерн & $\begin{array}{c}\text { Распространённость } \\
\text { процесса }\end{array}$ & Стадия (тяжесть) \\
\hline $\begin{array}{l}\text { «Матовое стекло» без } \\
\text { иных признаков }\end{array}$ & 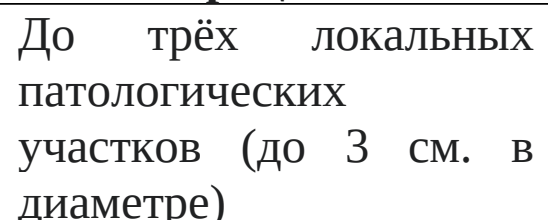 & Лёгкая КТ-1 \\
\hline $\begin{array}{l}\text { «Матовое стекло» без } \\
\text { иных признаков }\end{array}$ & 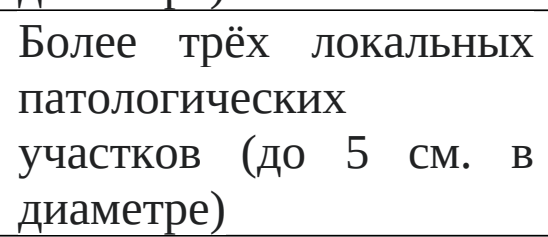 & Умеренная КТ-2 \\
\hline $\begin{array}{l}\text { «Матовое стекло» с } \\
\text { единичными участками } \\
\text { консолидации }\end{array}$ & & Средне-тяжёлая КT-3 \\
\hline $\begin{array}{l}\text { Диффузное уплотнение } \\
\text { лёгочной ткани по типу } \\
\text { «матового стекла» и } \\
\text { консолидации в } \\
\text { сочетании с } \\
\text { ретикулярными } \\
\text { изменениями }\end{array}$ & Практически диффузно & Тяжёлая КТ-4 \\
\hline
\end{tabular}


Рис. 40 Разновидность КТ-признаков заболевания (КT-1)
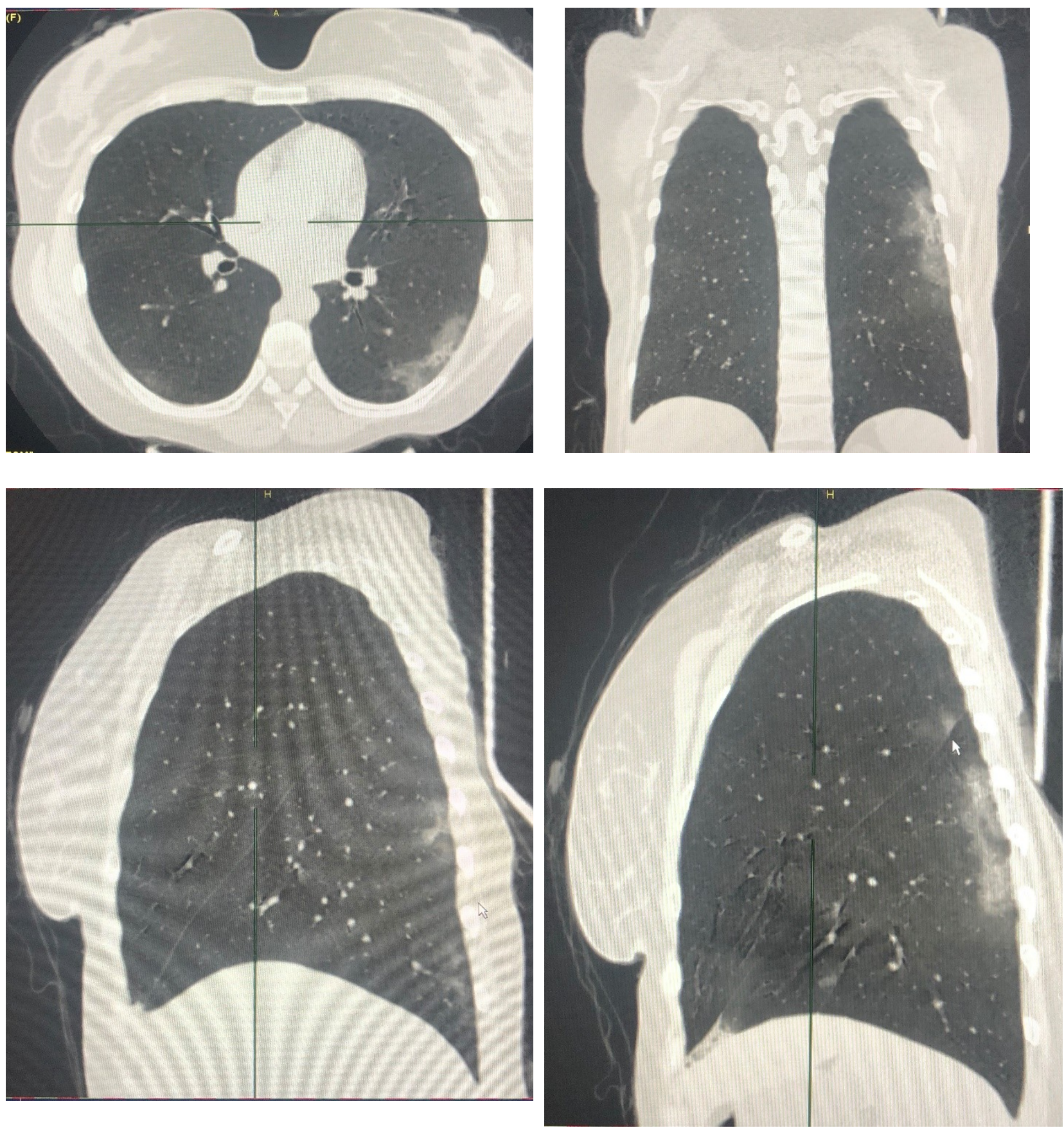
Рис. 41 Разновидность КТ-признаков заболевания (КТ-2)
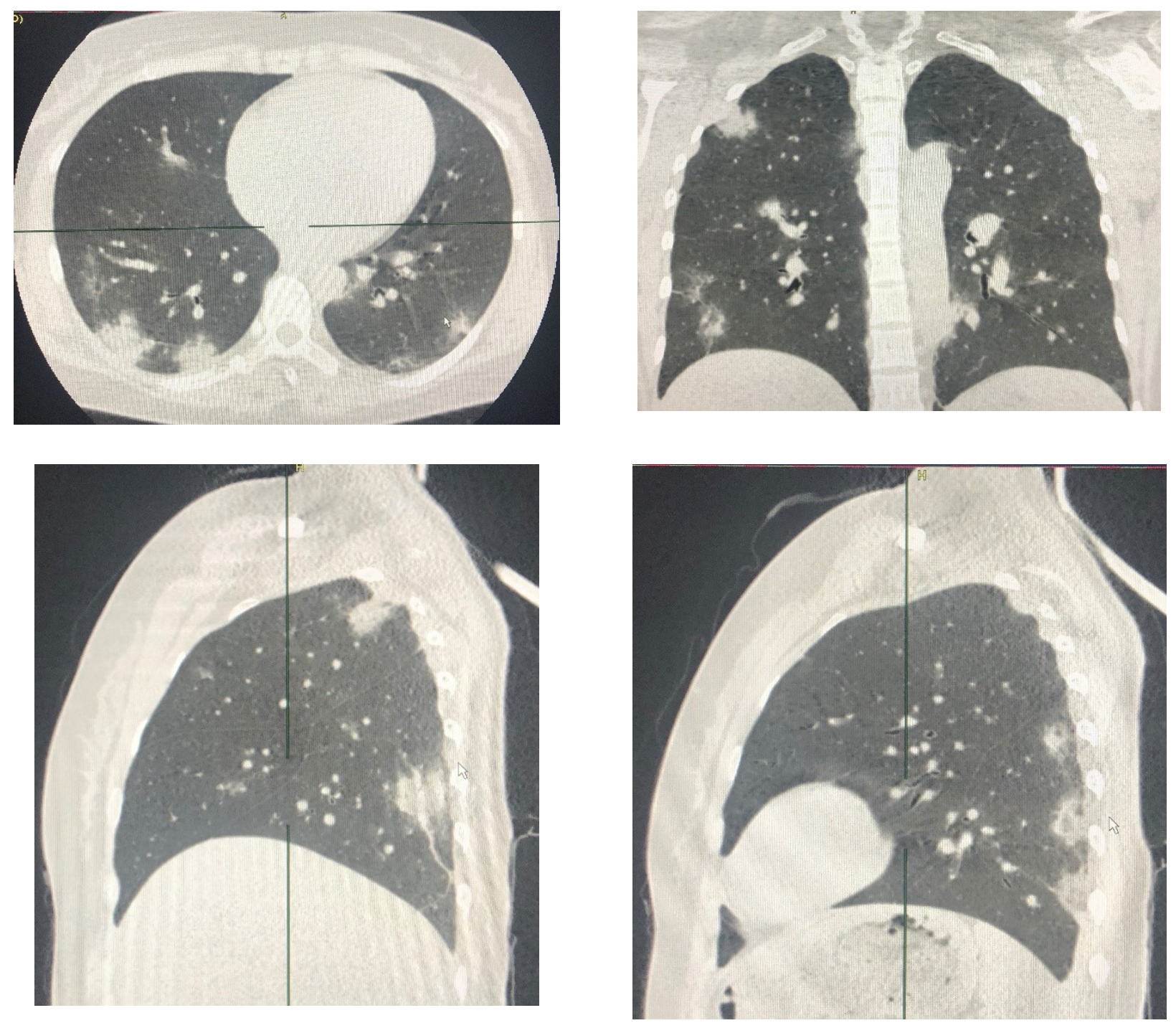
Рис. 42 Разновидность КТ-признаков заболевания (КT-3)
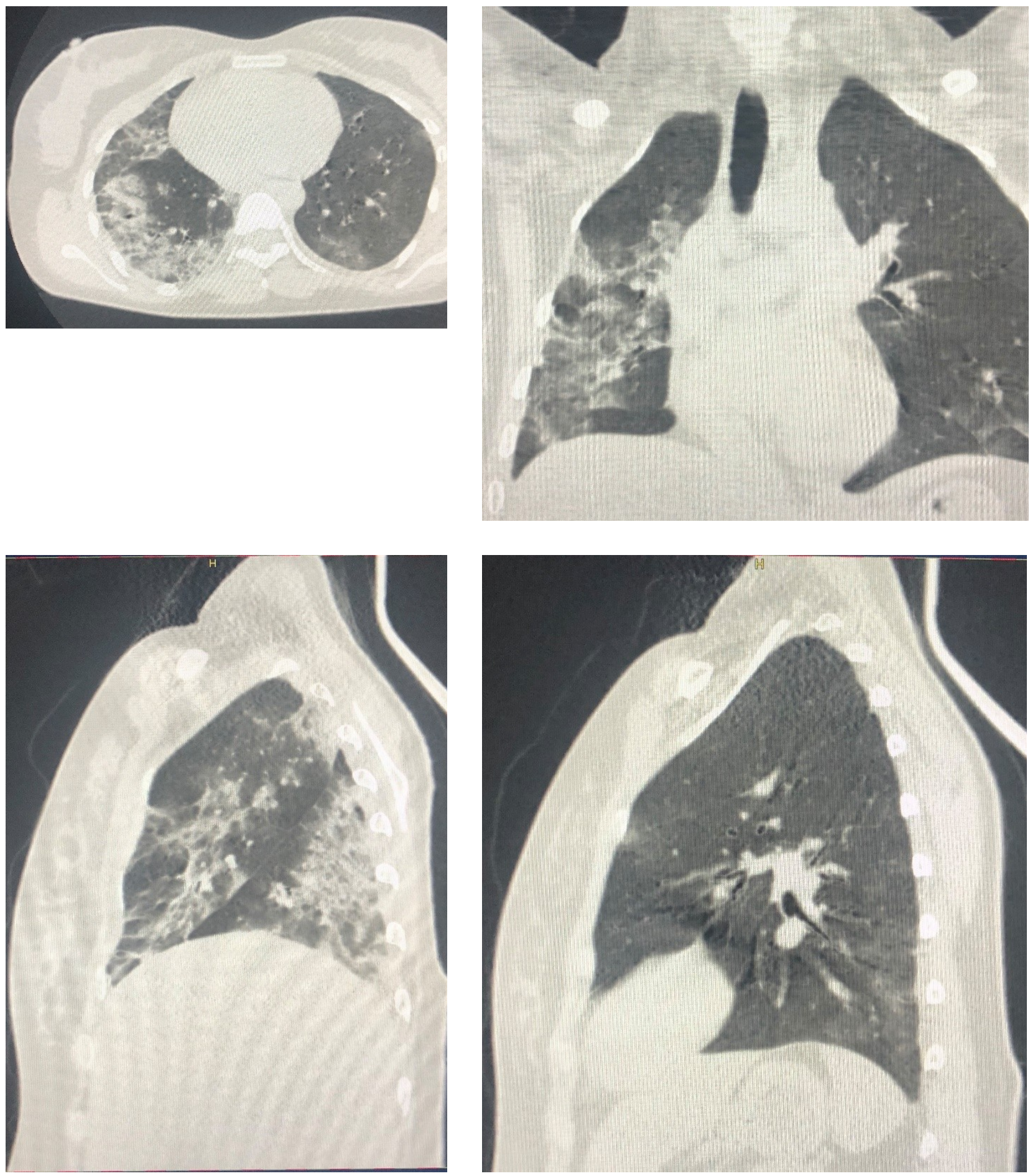
Рис. 43 Разновидность КТ-признаков заболевания (КT-4)
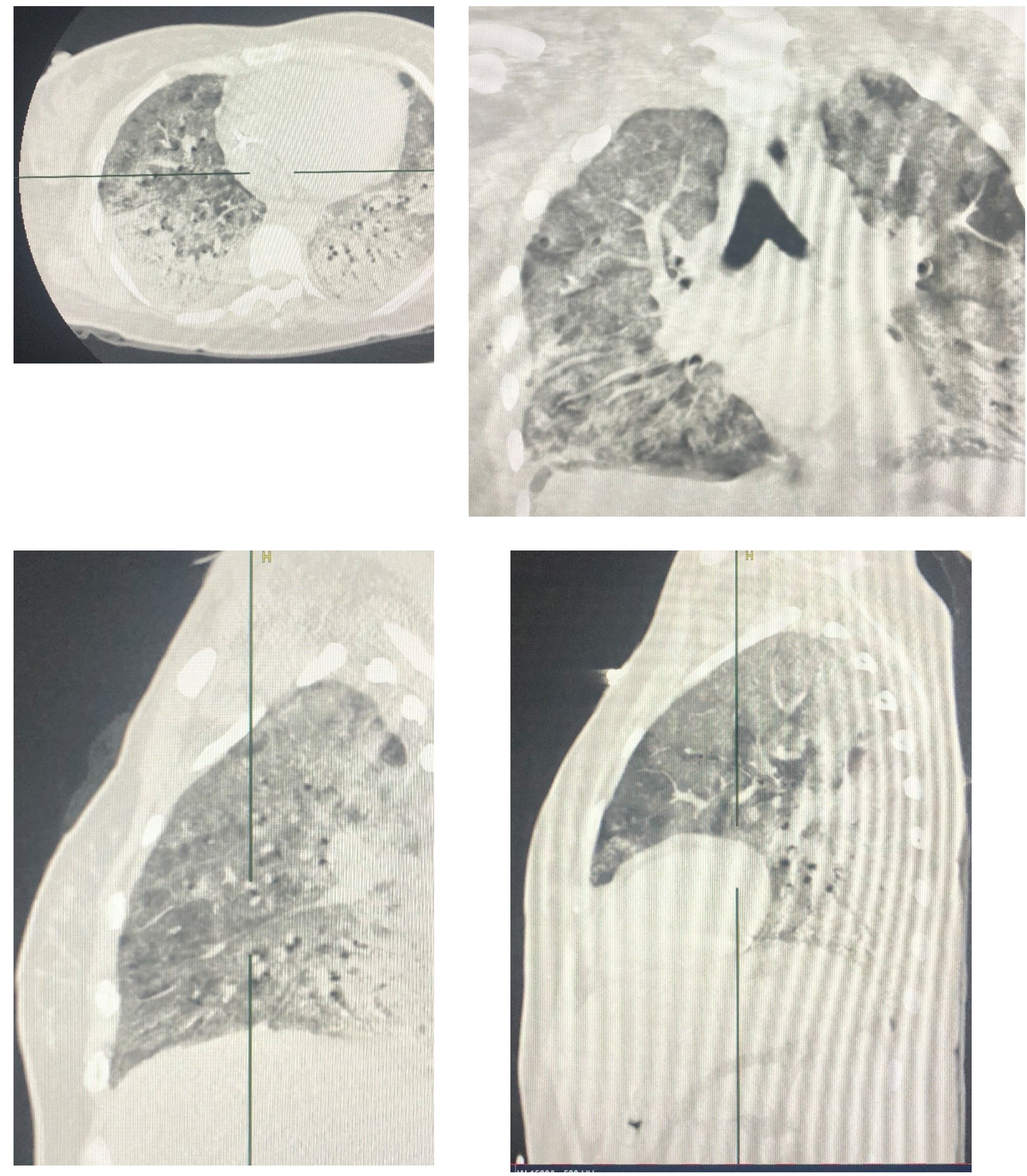
Данный вид диагностики оказывает помощь в трёх ключевых областях.

1) Изменения в лёгких настолько специфичны при COVID-19, что позволяют отдифференцировать от других возможных причин ОДН.

2) Определение изменений в лёгких у пациента, находящегося в пронпозиции на ИВЛ.

3) УЗИ лёгких легко проводить у постели больного, если по каким-либо причинам невозможно проведение компьютерной томографии.

Таблица 2. Тяжесть заболевания по данным УЗИ

\begin{tabular}{|c|c|c|}
\hline Тяжесть & УЗ-признаки & Дополнительно \\
\hline Лёгкая & $\begin{array}{l}\text { Наличие единичных В- } \\
\text { линий в межрёберном } \\
\text { промежутке } \\
\text { незначительные } \\
\text { интерстициальные } \\
\text { изменения }\end{array}$ & $\begin{array}{l}\text { Возможно наблюдение в } \\
\text { амбулаторных условиях }\end{array}$ \\
\hline Средняя & $\begin{array}{l}\text { Множественные B- } \\
\text { линии, } \quad \text { утолщение } \\
\text { плевральной линии - } \\
\text { умеренные } \\
\text { интерстициальные } \\
\text { изменения }\end{array}$ & $\begin{array}{c}\text { Показано срочное } \\
\text { проведение } \\
\text { компьютерной } \\
\text { томографии }\end{array}$ \\
\hline Тяжёлая & $\begin{array}{ll}\text { Консолидация } & \text { в } \\
\text { базальных отделах }\end{array}$ & $\begin{array}{c}\text { Показаны лечение в } \\
\text { ОРИТ, срочное } \\
\text { проведение } \\
\text { компьютерной } \\
\text { томографии }\end{array}$ \\
\hline
\end{tabular}

Принципы разграничения пациентов с подтвержденным и неподтвержденным (на этапе поступления) диагнозом COVID-19.

Таким образом, при поступлении больного в «ковидный» госпиталь, ещё на этапе приёмного отделения идёт разделение пациентов с подтверждённым диагнозом COVID-19 и пациентов с подозрением на данное инфекционное заболевание. Таким способом достигается «несмешивание» этих двух потоков во избежание «перекрестного» инфицирования.

Если у пациента, при наличии клиники и эпидемиологического анамнеза, присутствует хотя бы один из диагностических критериев (ПЦР «+», титры IgM, превышающие норму, или КТ-признаки высокой вероятности вирусного поражения), то такой больной направляется в «красную зону». 
Если диагноз сомнителен, то в условиях обсервационной палаты в течение суток производится дообследование и, если хотя бы один из вышеперечисленных критериев окажется в наличии, то больной также направляется в «красную зону».

Если диагноз на данный момент не подтверждается, но имеется заболевание другого рода или осложнение уже перенесенного COVID-19, то данный пациент госпитализируется в «синюю зону».

«Красная» и «синяя» зоны - это раздельные корпуса больницы. И у каждого из них имеет место своё приёмное отделение.

\section{Лечение COVID-19}

C момента начала эпидемии в КНР, «разросшейся» до масштабов пандемии, происходило непрерывное изучение самого вируса, его воздействия на организм, патогенеза заболевания с одной единственной целью - найти против него «оружие». Схемы лечения менялись по мере того, как медицинское сообщество всё больше узнавало про коронавирус SARSCoV-2 и вызываемую им болезнь COVID-19 [14,26,32,4-10]. K сожалению, этиотропное лечение по-прежнему не найдено. Большинство препаратов назначаются в режиме «off-label» (отсутствие доказательной базы, основываясь на международных рекомендациях и соотношениях пользы и риска).

В России руководством к действию являются клинические рекомендации Министерства здравоохранения Российской Федерации (М3 РФ). Учитывая количество пересмотров (на момент публикации - семь) за относительно короткий промежуток времени, становится понятно как стремительно менялись лечебные подходы к больным с COVID-19.

Первая версия клинических рекомендаций МЗ РФ опубликована 29.01.2020 г [4]. В качестве противовирусной терапии предлагался рибавирин. Использовался опыт лечения SARS- и MERS-CoV. Рибавирин

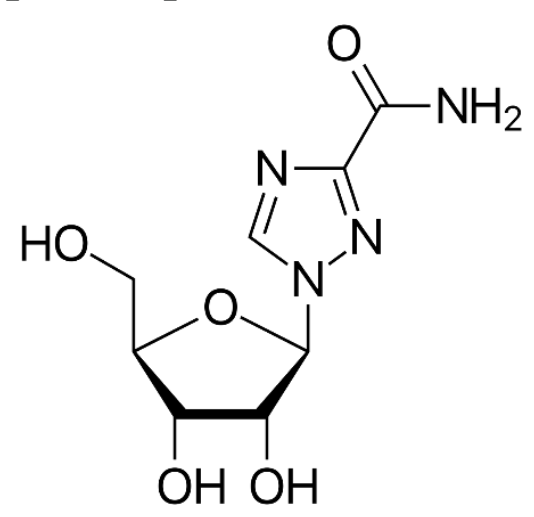

Рисунок 8 Структурная формула рибавирина (рис. 44) рекомендован в сочетании с лопинавиром и ритонавиром. Препараты интерферона-гамма должны были оказывать патогенетический эффект на заболевание, вызываемое 2019-nCoV (так ранее назван новый вирус).

Пациентам, у которых имела место клиника поражения нижних дыхательных путей (пневмония), показано было назначение антимикробных препаратов практически всех групп, в различных сочетаниях. 
Среди патогенетической терапии рассматривался вопрос о назначении ингибиторов протеолиза (протеаз и системных глюкокортикостероидов) в случаях тяжёлой пневмонии, осложнённой септическим шоком. В рекомендациях освещён вопрос о целесообразности назначения витаминов и дезинтоксикационной терапии. Предполагалось, что симптоматическая терапия должна была купировать лихорадку, явления ринита, бронхита (бронхолитики, мукоактивные препараты).

Вторая версия клинических рекомендаций МЗ РФ опубликована 03.02.2020 г. [5]. Дополнений по основным противовирусным препаратам не было. Но уже рекомендовано назначение противовирусных препаратов в случае средне-тяжёлого и тяжёлого течения инфекции, когда предполагаемая польза превышает потенциальный риск развития нежелательных явлений. То есть состав авторов данных рекомендаций обратил внимание на побочные эффекты данных препаратов. Также из рекомендаций по лечению удалили глюкокортикостероиды.

Третья версия клинических рекомендаций МЗ РФ опубликована 03.03.2020 г. [6]. В данной редакции рекомендовано назначение противовирусных препаратов в комбинациях (ранее применялись как монотерапия).

Четвёртая версия клинических рекомендаций МЗ РФ опубликована 27.03.2020 г. [7]. В качестве этиотропного лечения рассматриваются: комбинация лопинавир/ритонавир (Калетра ${ }^{\circledR}$ ), препараты интерферонов. Появляются в рекомендациях хлорохин и гидроксихлорохин. Коллективом авторов предлагается использовать такие свойства данных противомалярийных препаратов как противовоспалительные и иммунносупрессивные. Предпочтение отдаётся гидроксихлорохину с меньшей цитотоксичностью и более выраженным противовирусным эффектом. На основе небольших клинических исследований было доказано, что комбинация азитромицина с гидроксихлорохином усиливает противовирусный эффект последнего. Однако, обращается внимание на контроль кардиологом пациентов с данной терапией в связи с их кардиотоксичностью. Определены группы риска сердечно-сосудистых осложнений и необходимость контролировать интервал QT.

В патогенезе ОРДС вследствие COVID-19 упоминается избыточный ответ иммунной системы со стремительно развивающимся фатальным «цитокиновым штормом». Данная реакция ассоциирована с повышением интерлейкина-6. В качестве ингибиторов интерлейкина-6 более всего изучен (в КНР) тоцилизумаб (400 мг внутривенно капельно).

Согласно рекомендациям экспертов ВОЗ, глюкокортикостероиды добавляются в схемы лечения только в случае септического шока, но уже предпочтение отдаётся невысоким дозам и непродолжительным курсам.

Антибактериальная терапия по-прежнему рекомендуется всем больным с пневмонией наряду с симптоматической терапией. 
Большой раздел клинических рекомендаций посвящён реанимационным больным. Отдельное внимание уделяется детям и беременным женщинам.

Пятая версия клинических рекомендаций МЗ РФ опубликована 08.04.2020 г. [8]. Перечень противовирусных препаратов остаётся прежним. Более расширенно представлен патогенез заболевания.

Разработаны показания для введения тоцилизумаба: с 8 по 14 день сохраняющаяся или вновь появившаяся лихорадка, уровень Д-димера выше 1500 нг/мл, уровень интерлейкина-6 более 40 пг/мл и/или повышение уровня С-реактивного белка более 75 мг/л при интерстициальном поражении лёгких. Противопоказанием для назначения тоцилизумаба являются сепсис, нейтропения менее $0,5 \times 10^{9}$ /л, повышение АЛТ или АСТ более чем в 5 раз, тромбоцитопения менее $50 \times 10^{12} /$ л.

Рекомендуется вводить препарат в дозе 4-8 мг/кг (средняя доза 400 мг. в сутки), при неполном ответе эту дозу повторяют через 12 часов. Допускается максимум 4 дозы с интервалом 12 часов.

Впервые пациентам с тяжёлым течением COVID-19 рекомендовано включать низкомолекулярные антикоагулянты, так как высок риск развития ДВС-синдрома и венозной тромбоэмболии.

Шестая версия клинических рекомендаций МЗ РФ опубликована 28.04.2020 г. [9]. Наряду с уже общепризнанными этиотропными препаратами (гидроксихлорохин, лопинавир/ротанавир, азитромицин с гидроксихлорохином, препаратами интерферона), на стадии клинических испытаний ещё находились умифеновир, ремдесивир, фавипиравир. Появились указания, что рандомизированное контролируемое исследование выявило тот факт,что лечение в монорежиме лопинавир/ритонавир не продемонстрировало преимуществ перед симптоматической терапией. Таким образом, эффективность «Калетры» подвергнута сомнению.

Кроме того, препарат гидроксихлорохин также не продемонстрировал свою противовирусную активность,особенно при назначении в режиме моно. При этом, его комбинация с калетрой или азитромицином угрожает кумуляцией побочных эффектов.

Указывается, что ведётся разработка протоколов клинического применения антиковидной плазмы.

По-прежнему, к упреждающей «цитокиновый шторм» терапии относят блокаторы интерлейкина-6 (тоцилизумаб, сарилумаб). При отсутствии данных препартов необходимо по жизненным показаниям начать терапию глюкокортикостероидами (ГКС). Кроме того, при средне-тяжёлых формах пневмонии можно назначать таблетированный препарат барицитиниб (ингибитор янус-киназ). 
В данной редакции клинических рекомендаций расширены показания для назначения дексаметазона - у пациентов с ОРДС в низких дозах и кратковременным курсом (основываясь на том, что в случае с ОРДС без COVID-19, дексаметазон значительно снижал смертность).

Тактики назначения антикоагулянтной, антибактериальной и симптоматической терапии остаются прежними.

Седьмая версия (и пока последняя) клинических рекомендаций МЗ РФ опубликована 03.06.2020 г. [10]. В данных рекомендациях дан более расширенный блок патогенеза COVID-19. Впервые описаны кожные сыпи при данном заболевании.

Среди этиотропных препаратов перечислены всё те же лекарственные средства. Акцент в применении лекарственной терапии сделан на Фавипиравир. При этом имеется важное примечание: на данный момент времени нельзя сделать однозначный вывод об их эффективности или неэффективности. Поэтому их применение оформляется решением ВK, если потенциальная польза превышает риск их применения. Препарат Фавипиравир разрабатывался как ингибитор РНК-зависимой РНКполимеразы вируса гриппа. Исследование проводилось в КНР, Японии, начато в России.

Препараты гидроксихлорохина всё же рекомендованы к применению, но в меньших дозах и с обязательным мониторингом ЭКГ.

В данной редакции клинических рекомендаций указано, что Калетру можно использовать при наличии $\mathrm{y}$ пациентов противопоказаний $\mathrm{K}$ противомалярийным препаратам.

\section{В клинических рекомендациях указано на преимущество} Интерферон бета-1b.

Подробно расписаны изготовление, показания, противопоказания антиковидной плазмы.

В патогенетической терапии основная роль отводится таргетным препаратам и глюкокортикостероидам.

Блокаторы интерлейкина-6 - тоцилизумаб, сарилумаб. Для быстрого купирования «цитокинового шторма» тоцилизумаб назначается в дозе 4-8 мг/кг внутривенно в сочетании с глюкокортикостероидами (метилпреднизолон в дозе 0,5-1 мг/кг внутривенно каждые 12 часов или дексаметазон в дозе 20 мг/сутки в течение 2-3 суток с постепенным снижением дозы на 20-25\% на введение, каждые 1-2 суток). В дальнейшем, необходимость применения поддерживающей дозы метилпреднизолона 8-12 мг/сутки зависит от клинической ситуации. Обязательно сочетание с низкомолекулярными гепаринами вплоть до выписки. 
В седьмой версии клинических рекомендаций описано возможное применение моноклонального антитела к ИЛ-1 - канакинумаба в дозе 4-8 мг/кг внутривенно.

При средней и средне-тяжёлой формах пневмонии можно рассматривать назначение ингибиторов янус-киназ: барицитиниб и тофацитиниб, а также ингибитор интерлейкина- 6 околизумаба - в качестве дополнительной терапии. Эффективность их на тот момент была недостаточно изучена.

В седьмой версии клинических рекомендаций впервые обозначены строгие показания для назначения антибактериальной терапии - это убедительные признаки присоединения бактериальной инфекции (повышение уровня прокальцитонина более 0,5 нг/мл, лейкоцитоз более $10 \times 10 \%$ /л., появление гнойной мокроты). Также подробно в рекомендациях рассмотрены принципы терапии неотложных состояний, пребывания пациентов в реанимационных отделениях, указаны показания и противопоказания к экстракорпоральной мембранной оксигенации (ЭКМО).

Предложена терапия гелий-кислородными смесями.

Предложены методы экстракорпоральной детоксикации, гемокоррекции и нутриционной поддержки.

Разработана тактика ведения особых групп пациентов (с артериальной гипертензией, острым коронарным синдромом, сахарным диабетом и т.д.).

Изложены принципы медицинской реабилитации на 1, 2 и 3 этапах и порядок выписки из стационара.

И еще множество вопросов и проблем подняты и освещены в 7 версии клинических рекомендаций Министерства здравоохранения Российской Федерации.

Однако, в настоящее время медицинское сообщество ожидает пересмотра методических рекомендаций. В связи с тем, что в результате клинических исследований и наблюдений необходимо некоторые средства этиотропной терапии исключить, как неоправдавшие себя, и большее значение придать патогенетическим препаратам, в частности, глюкокортикостероидам и антикоагулянтам в лечебной дозе. 


\section{Опыт лечения COVID-19 в других клиниках}

Различные медицинские клиники, особенно располагающие научноисследовательской базой, попытались предложить свой путь в возможностях патогенетической терапии.

Для нашей клиники также были интересны рекомендации и накопленный опыт Медицинского научно-образовательного центра МГУ имени М.В. Ломоносова.

Согласно протоколу лечения базовая схема лечения, назначаемая госпитализированным пациентам средней тяжести и тяжёлым пациентам.

1. Бромгексин 8 мг х 4 раз в сутки

2. Спиронолактон 50 мг х 1 раз в сутки

3. Колхицин 1 мг в первый день, далее 500 мкг х 1 раз в сутки

4. Дипиридамол 75 мг х 2 раза в первый день, далее 150 мг х 2 раза в сутки

5. Антикоагулянты по уровню Д-димера и учитывая вес пациента. При клинических, либо инструментальных признаках тромбоза,

а также при инициации пульс-терапии рекомендовано использовать лечебные дозы низкомолекулярных гепаринов (с обязательным контролем функции почек!):

- Эноксапарин натрия (анфибра, клексан, эниксум) 1 мг/кг х 2 раза в сутки или

- Надропарин кальция 0,4 мл (при массе тела менее 50 кг),

0,6 мл (при массе тела 50-70 кг),

0,8 мл (при массе тела более 80 кг) х 2 раза в сутки

Упреждающая противовоспалительная терапия назначается при наличии двух и более признаков:

1) $\mathrm{SpO} 2$ менее 93\% при дыхании воздухом

2) С-реактивный белок более 60 мг/л или рост СРБ в 3 раза и более на 814 дни заболевания

3) Лихорадка более $38,5^{\circ} \mathrm{C}$ в течение 5 дней

4) Количество лейкоцитов менее $3,0-3,5$ × $10^{9} /$ л

5) Количество лимфоцитов менее $1,0 \times 10^{9} / л$

В качестве противовоспалительной терапии могут быть использованы следующие препараты:

1. Глюкокортикостероиды 0,5 мг/кг (в пересчёте на преднизолон) 2 раза в сутки или пульс-терапия Метилпреднизолоном 1000 мг внутривенно 1 раз в сутки в течение 3-х дней

2. Колхицин - 1 мг х 1 раз в сутки - 3 дня, далее по 500 мкг х 1 раз в сутки 
3. Тоцилизумаб (анти ИЛ-6) 800 мг внутривенно (в виде инфузий однократно или 2 введения по 400 мг с интервалом в 12 часов).

4. Секукинумаб (анти ИЛ-17А) 300 мг подкожно (в виде двух отдельных инъекций по 150 мг)

5. Канакинумаб 450-600 мг подкожно (с учётом возраста, масса тела)

6. Руксолитиниб 5 мг х 2 раза в сутки (принимается внутрь)

Со многими из этих позиций можно обоснованно согласиться. Так, колхицин - это алкалоид трополонового ряда (гомоморфинанов). Учитывая его способность уменьшать высвобождение лизосомальных ферментов нейтрофилов, их готовности к воспалительной инфильтрации со снижением скорости миграции была рассмотрена возможность их применения при COVID-19.

Дипиридамол также может оказывать позитивное влияние на систему микроциркуляции, серьёзно страдающую при COVID-19, как ангиопротектор и корректор микроциркуляции.

Бромгексин оказывает непрямое муколитическое, отхаркивающее и противокашлевое действие. Улучшает проходимость дыхательных путей Амброксол (активный метаболит бромгексина) стимулирует синтез сурфактанта альвеолярными пневмоцитами 2 порядка. Это способствует разделению бронхиальной слизи на гелевую и зольную фазы, уменьшая её адгезивность и восстанавливая мукоцилиарный клиренс.

Верошпирон оказывает ингибирующее действие на альдостерон, а значит, и всю последующую цепочку взаимодействий, включая гиперангиотензиногенемию, которая имеет место в патогенезе COVID-19 (вирус использует для проникновения в клетку ACE-2 рецепторы, некоторым образом, активируя их). 


\section{Заключение}

Таким образом, человечество на рубеже 2019-2020 гг. столкнулось с эпидемией новой коронавирусной инфекции, быстро перешедшей в пандемию. Вирус SARS-CoV-2 отмечается от своих таких же агрессивных и вирулентных собратьев как SARS-CoV и MERS-CoV. Из зоомира вирусу удалось перейти в новую среду обитания - на человека. И, благодаря своей контагиозности и современному устройству Мира (свободное и быстрое передвижение человека), вирус быстро «освоил» практически весь Мир. Не сразу, а только по мере накопления наблюдения за его поведением, за процессами, которые вирус запускает в организме, постепенно складывалась целостная картина заболевания. Разрушительная сила вируса оказалась в типе и степени реагирования иммунной системы человека на вирус как на триггер.

Так же менялись наши взгляды на принципы лечения данной патологии. Этим объясняется такое количество пересмотров Министерством здравоохранения Российской Федерации рекомендаций «Профилактика, диагностика и лечение новой коронавирусной инфекции (COVID-19)» и все они имеют определение «временные». Это был и есть основополагающий документ для медицинского сообщества России. На базе этого документа лечебные учреждения разрабатывали свои алгоритмы, адаптировали к условиям и возможностям каждого инфекционного стационара, перепрофилированного из многопрофильных больниц для работы в условиях пандемии.

\section{Выводы:}

Какие можно сделать выводы по лечебной тактике ведения больных COVID-19 в условиях нашего стационара за прошедшие месяцы?

1) Очевидно, что схемы лечения менялись, согласно изменениям вносимым в клинические рекомендации Министерства здравоохранения всех семи пересмотров.

2) По-прежнему, большинство препаратов назначаются в режиме «offlabel» (отсутствие доказательной базы, но основываясь на международных рекомендациях и соотношении пользы и риска).

3) Нужно отметить, что этиотропное лечение по-прежнему не найдено. Предпринимались попытки применения различных противовирусных препаратов, неплохо зарекомендовавших себя при других инфекциях (ВИЧ, лихорадка Эбола, вирусов SARS-CoV и MERS-CoV). K ним относятся фавипиравир, лопинавир + ритонавир, препараты интерферонов, умифеновир, ремдесивир. Была предпринята попытка использовать иммунносупрессивный эффект противомалярийных препаратов (гидроксихлорохин, хлорохин, инфлохин), которые также используются в ревматологической практике. 
4) Один из антибиотиков группы макролидов (азитромицин) применялся с гидроксихлорохином в комбинации для потенцирования иммунносупрессивного ответа.

5) Однако, на практике пришлось отказаться (хотя в рекомендациях они ещё сохраняются) от широкого применения гидроксихлорохина и лопинавир/ритонавира в связи с плохой переносимостью, диспепсическими расстройствами, что не только утяжеляло объективный статус больных, но и не давало желаемого эффекта. В процессе наблюдения за пациентами не сложилось впечатления, что данные препараты способны предупреждать развитие «цитокинового шторма» и, тем более, его купировать. Кроме того, применение плаквенила совместно с азитромицином приводило у определённого процента больных к удлинению интервала QT и проаритмогенному эффекту.

6) На данный момент активнее остальных противовирусных препаратов используется фавипиравир (разрабатывался как ингибитор РНКзависимой полимеразы вируса гриппа). По этому препарату уже проведён ряд исследований в Китае, Японии, России, продемонстрировавших неплохой результат. Условием для его назначения является клиническая картина COVID-19, положительный результат ПЦР на SARS-CoV-2 в биоматериале, взятом из носа и ротоглотки. То есть фавипиравир эффективнее работает в дебюте заболевания, на этапе внедрения, когда вирус ещё сохраняется в верхних дыхательных путях. Препарат имеет строгие показания и противопоказания, может применяться только в условиях стационара.

7) Учитывая наличие гипериммунного избыточного ответа организма на внедрение вируса («цитокиновый шторм»), обоснованным является назначение биологических препаратов - ингибиторов интерлейкина- 6 (тоцилизумаб), интерлейкина-1 (анакинра). В нашей клинике используется тоцилизумаб (актемра).

8) Показанием для назначения янус-киназ (барицитиниба) являются клиника «цитокинового шторма» и стадия заболевания КТ 2-3.

9) Учитывая «извращённый» иммунный ответ с элементами аутоиммунного повреждения, мы смелее стали использовать глюкокортикостероиды с хорошим эффектом. В критических ситуациях - по схеме пульс-терапии и в средних и малых дозах на начальных этапах болезни, но уже с первыми признаками «цитокинового шторма».

10) В связи с острой вирусной инфекцией, применением генноинженерных биологических препаратов, стероидов, повышается риск вторичной бактериальной инфекции. И только при появлении клиниколабораторно-инструментальных ее признаков (гнойность мокроты, участки консолидации в лёгких, повышение уровня лейкоцитов больше $10 \times 10^{9} /$ и и прокальцитонин более 0,5 нг/мл) назначаются антибактериальные препараты. Но никак не с первого дня развития пневмонии, как это было рекомендовано в первых нескольких 
пересмотрах клинических рекомендаций. Дело в том, что термин «пневмония» в добактериальный период не совсем оправдан, скорее применим термин «пневмонит». А это предполагает уже другую тактику.

11) В патогенезе заболевания следствием гипериммунного ответа являются нарушения в системе свёртывания крови. Практически всем больным при отсутствии противопоказаний назначаются низкомолекулярные гепарины в лечебной дозе с первого дня госпитализации до последнего.

12) С целью лучшего отхождения мокроты назначают мукоактивные препараты, бронхолитики при бронхообструктивном синдроме.

13) Респираторная поддержка была и остаётся одним из основных методов лечения. Начиная от ингаляции увлажнённым кислородом,с переходом в прон-позицию до различных режимов ИВЛ. В крайне тяжёлых случаях применяется метод ЭКМО (но реанимационный этап лечения, экстракорпоральные методы не являлись целями рассмотрения в данной статье).

14) $\mathrm{C}$ жаропонижающей целью применялся парацетамол. Нестероидные противовоспалительные препараты, учитывая их противовоспалительный эффект, также находили свое применение.

15) Некоторые препараты, учитывая особенности патогенеза заболевания, также нашли свою нишу в схеме лечения (off-label), особенно, начальных нетяжёлых форм. Это колхицин, спиронолактон, дипиридамол, высокие дозы аскорбиновой кислоты, витамин Д. 


\section{СПИСОК ЛИТЕРАТУРЫ}

1. Авдеев С.Н. Практические рекомендации по кислородотерапии и респираторной поддержке пациентов с COVID-19 на дореанимационном этапе. //Пульмонология. 2020 - Т.30(2) - с. 151-153.

2. Вопросы и ответы о COVID-19. Всемирная организация здравоохранения. Дата обращения 01.03.2020

3. Вопросы и ответы о COVID-19. Всемирная организация здравоохранения. Дата обращения 10.08.2020

4. Профилактика, диагностика и лечение новой коронавирусной инфекции (COVID-19). Временные методические рекомендации. Министерство здравоохранения Российской Федерации. Вер. 1 (29.01.2020)

5. Профилактика, диагностика и лечение новой коронавирусной инфекции (COVID-19). Временные методические рекомендации. Министерство здравоохранения Российской Федерации. Вер. 2 (03.02.2020)

6. Профилактика, диагностика и лечение новой коронавирусной инфекции (COVID-19). Временные методические рекомендации. Министерство здравоохранения Российской Федерации. Вер. 3 (03.03.2020)

7. Профилактика, диагностика и лечение новой коронавирусной инфекции (COVID-19). Временные методические рекомендации. Министерство здравоохранения Российской Федерации. Вер. 4 (27.03.2020)

8. Профилактика, диагностика и лечение новой коронавирусной инфекции (COVID-19). Временные методические рекомендации. Министерство здравоохранения Российской Федерации. Вер. 5 (08.04.2020)

9. Профилактика, диагностика и лечение новой коронавирусной инфекции (COVID-19). Временные методические рекомендации. Министерство здравоохранения Российской Федерации. Вер. 6 (28.04.2020) 10. Профилактика, диагностика и лечение новой коронавирусной инфекции (COVID-19). Временные методические рекомендации. Министерство здравоохранения Российской Федерации. Вер. 7 (03.06.2020)

11. Рекомендации BO3 для населения в связи с распространением нового коронавируса (2019-nCoV): мифы и ложные представления.

12. Aylward B., Liang W. Report of the WHO-China Joint Mission on Coronavirus Disease 2019 (COVID-19) // The WHO-China Joint Mission on Coronavirus Disease 2019. 2020.

13. Beeching N. J., Fletcher T. E., Fowler R. BMJ best practice: COVID-19 // The BMJ. 2020.

14. Cascella M. [и др.]. Features, Evaluation and Treatment Coronavirus (COVID-19) / M. Cascella, M. Rajnik, A. Cuomo, S. C. Dulebohn, R. Di Napoli, 2020. 
15. CDC Interim Clinical Guidance for Management of Patients with Confirmed Coronavirus Disease (COVID-19) // Centers for Disease Control and Prevention. 2020.

16. Centers for Disease Control and Prevention Coronavirus Disease 2019 (COVID-19) Situation Summary // Journal of Medical Virology. 2020.

17. Centers for Disease Control and Prevention (CDC) Interim Clinical Guidance for Management of Patients with Confirmed Coronavirus Disease (COVID-19) // Centers for Disease Control and Prevention. 2020.

18. Disease background of COVID-19 // European Centre for Disease Prevention and Control. 2020

19. Dong Ү. [и др.]. Epidemiology of COVID-19 among children in China // Pediatrics. 2020.

20. Eastin C., Eastin T. Epidemiological characteristics of 2143 pediatric patients with 2019 coronavirus disease in China: Dong Y, Mo X, Hu Y, et al. Pediatrics. 2020; doi: 10.1542/peds.2020-0702 // Journal of Emergency Medicine. 2020.

21. Guan W. [и др.]. Clinical characteristics of coronavirus disease 2019 in China // New England Journal of Medicine. 2020.

22. Halfmann P. J. [и др.]. Transmission of SARS-CoV-2 in Domestic Cats // New England Journal of Medicine. 2020.

23. Heymann D. L., Shindo N. COVID-19: what is next for public health? // The Lancet. 2020.

24. National Center for Immunization and Respiratory Diseases (NCIRD) D. of V. D. Interim Clinical Guidance for Management of Patients with Confirmed Coronavirus Disease (COVID-19) // Centers for Disease Control and Prevention. 2020.

25. New Images of Novel Coronavirus SARS-CoV-2 Now Available. //NIAID Now U.S. National Institute of Allergy and Infection Diseases. 2020

26. Porter R. S., Kaplan J. L. The Merck Manual of Diagnosis and TherapyNineteenth edition 2011.

27. Rodriguez-Morales А. Ј. [и др.]. Clinical, laboratory and imaging features of COVID-19: A systematic review and meta-analysis // Travel Medicine and Infectious Disease. 2020.

28. Shang J. [и др.]. Cell entry mechanisms of SARS-CoV-2 // Proceedings of the National Academy of Sciences of the United States of America. 2020.

29. Sharing research data and findings relevant to the novel coronavirus (COVID-19) outbreak. Wellcome. 2020.

30. Spinato G. [и др.]. Alterations in Smell or Taste in Mildly Symptomatic Outpatients with SARS-CoV-2 Infection // JAMA - Journal of the American Medical Association. 2020.

31. Symptoms //2019 Novel Coronavirus, Wuhan, China. - Centers for Disease Control and Prevention (CDC)

32. Tingbo L. Handbook of COVID-19 Prevention and Treatment // Handbook of Covid-19, Prevention and Treatment. 2020. 
33. WHO Clinical management of severe acute respiratory infection when novel coronavirus (2019-nCoV) infection is suspected. interim guidance // WHO. 2020. 34. WHO World Health Organization. Pneumonia of unknown cause - China. 2020.

35. Wong J. E. L., Leo Y. S., Tan C. C. COVID-19 in Singapore - Current Experience: Critical Global Issues That Require Attention and Action // JAMA Journal of the American Medical Association. 2020.

36. World Health Organization Clinical management of severe acute respiratory infection when novel coronavirus (nCoV) infection is suspected // Who. 2020.

37. World Health Organization Coronavirus Disease 2019 Situation Report 50 // A \& A Practice. 2020.

38. Хia W. [и др.]. Clinical and CT features in pediatric patients with COVID19 infection: Different points from adults // Pediatric Pulmonology. 2020.

39. Үао Ү. [и др.]. No association of COVID-19 transmission with temperature or UV radiation in Chinese cities // European Respiratory Journal. 2020.

40. Ye G. [и др.]. Clinical characteristics of severe acute respiratory syndrome coronavirus 2 reactivation // Journal of Infection. 2020. 